This item was submitted to Loughborough's Research Repository by the author.

Items in Figshare are protected by copyright, with all rights reserved, unless otherwise indicated.

\title{
Assessing the role of host country human rights protection on multinational enterprises' choice of investment strategy
}

\section{PLEASE CITE THE PUBLISHED VERSION}

https://doi.org/10.1007/s11575-020-00413-y

\section{PUBLISHER}

Springer Science and Business Media LLC

\section{VERSION}

AM (Accepted Manuscript)

\section{PUBLISHER STATEMENT}

This is a post-peer-review, pre-copyedit version of an article published in Management International Review. The final authenticated version is available online at: https://doi.org/10.1007/s11575-020-00413-y.

\section{LICENCE}

CC BY-NC-ND 4.0

\section{REPOSITORY RECORD}

Rao-Nicholson, Rekha, and Luda Svystunova. 2020. "Assessing the Role of Host Country Human Rights Protection on Multinational Enterprises' Choice of Investment Strategy”. Loughborough University. https://hdl.handle.net/2134/13228754.v1. 
Assessing the role of host country human rights protection on multinational enterprises' choice of investment strategy

\author{
Rekha Rao-Nicholson* \\ Essex Business School \\ University of Essex \\ Colchester, United Kingdom \\ rekha.raonicholson@essex.ac.uk
}

Liudmyla Svystunova

Institute for International Management, Loughborough University London

Loughborough University

London, United Kingdom

1.svystunova@1boro.ac.uk

*corresponding author 


\begin{abstract}
Although international business studies have examined the role of non-market factors in multinational enterprises' (MNEs) foreign ownership, there is a limited focus on the role of host country human rights records on MNEs' ownership decisions. Further, there is little understanding of the differences in ownership decisions between the developed country multinational enterprises (DMNEs) and emergingmarket multinational enterprises (EMNEs) as influenced by the non-market context of their host countries. This study, therefore, explores the links between the host country's human rights governance and MNEs' ownership strategy in cross-border acquisitions. We argue that clarity in human rights governance in the host country will encourage MNEs to establish higher stakes in local targets and that this relationship will be stronger for DMNEs than for EMNEs. Our findings, which support these hypotheses, offer insights into the relationship between MNE investment strategy and human rights governance, and inform the debate on the differences between internationalization strategies of EMNEs and DMNEs.
\end{abstract}

Short title: Human rights and MNEs' investments

Keywords: human rights, developed market multinationals (DMNEs), emerging market multinationals (EMNEs), cross-border investments, host country characteristics, ownership strategy

Declarations: Not applicable

Acknowledgements: We thank the editor, Michael-Jörg Oesterle, and the two anonymous reviewers for their guidance and valuable suggestions throughout the review process. We also appreciate helpful comments from the participants at the 2018 Academy of Management Meeting and the 2018 meeting of the UK \& Ireland Chapter of the Academy of International Business in Birmingham. 


\section{Introduction}

With growing concerns from governments and civil society about the enforcement of fundamental human rights, multinational enterprises (MNEs) increasingly face new societal demands (Kolk, 2016). These developments have given rise to studies on the non-market environment of international business, which considers the impact of issues such as climate change, child labor and access to health on global and local MNE strategies (Doh \& Lucea, 2013). Much of the research on MNEs and human rights is concerned with intra-organizational policies and MNE misconduct, particularly in developing countries (Scherer \& Palazzo, 2011). Yet, in contrast to the considerable amount of literature on MNE strategy and host country corruption prevalence (Collins, Uhlenbruck \& Rodriguez, 2009; Cuervo-Cazurra, 2006), studies examining similar effects of the human rights context remain sparse (Giuliani \& Macchi, 2014; Wettstein, Giuliani, Santangelo \& Stahl, 2019). In this paper, we consider human rights as one of the societal concerns which can influence internationalizing firms' ownership strategy.

Human rights have been in the spotlight in recent decades, with the efforts of social movements and global governance initiatives such as the UN Global Compact, or the Corporate Human Rights Benchmark. By directly engaging with businesses, they are increasingly drawing the attention of managers to local human rights concerns (Garriga, 2016; Maggioni, Santangelo \& Koymen-Ozer, 2019; Orentlicher \& Gelatt, 1993; Spar, 1998). As a result, a number of scholars have recently argued for the need to understand how MNEs from both developed and developing markets, engage with human rights issues in their foreign operations (Giuliani, Santangelo \& Wettstein, 2016; Wettstein et al., 2019). Our study focuses on how the under-researched area of human rights as one of the dimensions of the nonmarket environment within a country, impacts strategic choice in ownership by MNEs, and whether there is a difference between the strategic choice in ownership adopted by the developed country multinational enterprises (DMNEs) and that of emerging-market multinational enterprises (EMNEs).

Ownership decisions require "significant resource commitments, including managerial expertise and coordination time, and, once established, have long-term consequences for the company" (Di Guardo, Marrocu \& Paci, 2016: 4225). Hence, in cross-border mergers and acquisitions, investors 
have been shown to adjust the extent of control in target companies in response to the challenges posed by the host country environment and the associated strategic and operational considerations (Anderson \& Gatignon, 1986; Uhlenbruck, Rodriguez, Doh \& Eden, 2006). Our baseline assertion is that MNEs will acquire higher ownership stakes in host countries with clarity in the human rights governance as this helps managers align their strategies with the local human rights concerns effectively, thus reducing uncertainty regarding potential future challenges to their foreign operations.

At the same time, it is crucial to consider the role of the MNEs' home country context as there is an inherent difference between the MNEs that originate from the developed markets as compared to those from the emerging markets that generally develop from locations where non-market environment is comparatively volatile (Cuervo-Cazurra, Luo, Ramamurti \& Ang, 2018; Khanna \& Palepu, 1997). We argue that these dissimilar home country contexts will likely be associated with differences in, not only strategic aspirations (Buckley, 2018), but also stakeholder expectations and capabilities to deal with challenges in the non-market environment which, in turn, have implications for their internationalization strategies. Many of EMNEs' home countries are characterised by limited development and implementation of human rights governance, and they might lack both experience and external credibility in engaging with human rights practices (Fiaschi, Giuliani \& Nieri, 2017). Yet, these aspirant EMNEs have proactively engaged in catch-up activities (Liou \& Rao-Nicholson, 2019; Luo \& Tung, 2007), including building their skills and targeting countries with good governance (Deng \& Yang, 2015; Han, Liu, Gao \& Ghauri, 2018). Similar to views presented by Chikhouni, Edwards and Farashahi (2017), we therefore propose that since prior understanding of internationalization and ownership have largely been derived from studies on DMNEs, when considering the role of the nonmarket environment in MNE ownership decisions, it is useful to adopt a comparative approach that is sensitive to potential differences between the strategies of EMNEs and DMNEs. Specifically, we expect that EMNEs will be less deterred by challenges in human rights governance than their DMNE counterparts.

To test our hypotheses regarding the influence of human rights governance in the host country on ownership decisions, we use a matched sample of 2802 deals conducted by DMNEs and EMNEs in 
79 target destinations. The findings of our study contribute to two streams of literature. Our main contribution is to the debate on the role of the non-market environment in strategic choices made by MNEs (Di Guardo et al., 2016; Uhlenbruck et al., 2006), namely the role of host country human rights regimes in MNE ownership strategies. By examining this relationship, we contribute to the emergent literature on the complex relationship between MNEs and human rights (Hsieh, 2015; Sullivan, 2017; Wettstein et al., 2019) where evidence remains largely anecdotal, and the broader debate on the links between MNEs and the non-market context of their activities (Puck, Lawton \& Mohr, 2018). The results of our study show that the non-market environment within a host country, specifically human rights governance, has a significant impact on the ownership levels adopted by the MNEs. We show that firms prefer countries with better human rights governance when it comes to acquiring higher stakes in their targets.

Secondly, our study supports the view that there is a need to further qualify the discussion of the non-market environment implications for MNEs (Voinea \& van Kranenburg, 2018) by considering the appeal of better human rights governance to DMNEs and EMNEs. We extend the studies of foreign direct investment (FDI) by MNEs and especially comparative work examining FDI strategies of DMNEs and EMNEs informed by the non-market environment (Cuervo-Cazurra, 2012; Gaffney, Karst \& Clampit, 2016; Malhotra, Lin \& Farrell, 2016) by explicating how host country context and home country conditions combine to influence the strategic choices of these firms. By focusing on host country human rights governance as a source of challenges for MNEs, we add a further nuanced view on how DMNEs and late-internationalizing EMNEs perceive environmental challenges in host countries. Our findings show that human rights governance is of higher salience to DMNEs as compared to EMNEs, thus indicating that DMNEs are particularly reluctant to engage in host countries with potentially more challenging non-market environments. Importantly, however, we find that although to a lesser extent, human rights governance considerations are nevertheless also noteworthy to EMNE investors. These results, therefore, inform the debate on the differences between internationalization strategies of EMNEs and DMNEs (Chikhouni et al., 2017; Estrin, Meyer \& Pelletier, 2018) and draw 
our attention to the idea of potential convergence between the EMNEs' and DMNEs' approach to dealing with host country human rights.

\section{Theoretical background and hypothesis development}

\subsection{Host country non-market environment, human rights governance, and MNEs}

According to Baron (1995: 47-48), the non-market environment spans "the social, political and legal arrangements that structure the firm's interactions outside of, and in conjunction with, markets." Our understanding of the non-market environment is informed by institutional theory, according to which these arrangements can be conceptualised as encapsulated in formal and informal institutions (De Villa, Rajwani \& Lawton, 2015), the "humanly devised constraints" or "the rules of the game in a society" (North, 1990: 3). Whereas formal rules consist of codified rules and regulations, informal institutions include unwritten rules such as values, beliefs, norms and behaviors (ibid). Both formal and informal institutional environments can pose substantive challenges to MNEs, particularly at the point of entry when investors are less familiar with the local context (Slangen \& van Tulder, 2009), and institutions might therefore affect investors' risk perceptions (De Villa et al., 2015). Although political risk, policy instability and regulatory constraints on market transactions are a well-studied area of international business (Delios \& Henisz, 2003), studies of the non-market environment and its implications for MNEs have focused on a relatively narrow set of issues (Doh \& Lucea, 2013; Voinea \& van Kranenburg, 2018). The majority of these insights into the role of non-market context in MNE strategy comes from the work on corruption (Duanmu, 2011; Karhunen \& Ledyaeva, 2012). As such, there is a gap in the literature on other non-market factors that might influence the MNEs' internationalization activities (Voinea \& van Kranenburg, 2018). We propose human rights governance in the host country to be one such issue.

Ang and colleagues (2015) considered human rights in aggregate, as a subset of governance matters, alongside civil rights, political stability and law enforcement. They suggest that this group of institutions is, in fact, not always explicitly codified and thus can also represent a challenge in crossborder business transactions. From a more fine-grained perspective, as a dimension of non-market environment, human rights typically encompass a host of physical integrity rights (such as freedom 
from politically-motivated imprisonment, murders and torture) as well as civil and political liberties (including the ability to freely practice religion, travel within and outside the country and participate in politics and union activities), the respect for which differs across states (Cingranelli \& Richards, 2010; Richards, Gelleny \& Sacko, 2001). Viewed in this way, human rights can be conceptualised as realized in practices espoused by the host governments.

Challenges related to the human rights governance in the host country can arise from the lack of formalization of social issues as such, or the poor alignment between formal and informal institutions (Liedong \& Frynas, 2018; Sen, 2007). Indeed, some aspects of human rights can well be codified into national laws (i.e. in the case of states ratifying human rights treaties and covenants and translating them into national laws or formal rules), but the state of a particular host country may not be willing or able to ensure respect of these laws (as suggested by the informal, unwritten rules). For investors and local actors alike, these differences between human rights, as codified in policy and realized in practice, might then represent deviations from the written rules and regulations within the host country (Simons \& Macklin, 2014). The other scenario would be that human rights are not even codified into national laws (e.g., the state has not ratified certain human rights treaties, or it has ratified them but failed to transform them into national legislation afterward). Indeed, both situations would lead to weaknesses in the capacity of governments to ensure respect and promotion of certain human rights: from nonexistent observance in the case of no ratification or no national laws, to inadequate observance in the case of informal and formal rules being misaligned. Previous works have also argued that infringements of human rights by the state are often an indicator of a broader set of governance failures which deter foreign investors by posing social and economic risks to MNE operations (Arregle, Miller, Hitt \& Beamish, 2013; Blanton \& Blanton, 2007).

Notably, international business studies concerned with human rights implications for MNE conduct have predominantly looked inside the MNE, examining global corporate social responsibility (CSR) practices and their local adaptation, or human rights reporting (Kolk, 2005; Kolk \& Lenfant, 2010; Obara \& Peattie, 2018; Wettstein, 2012). As such, understanding how businesses respond to 
human rights governance remains "perhaps the central impetus for the BHR [business and human rights] discussion" (Wettstein et al., 2019: 58).

\subsection{Non-market environment, human rights governance and MNE ownership}

When engaging in cross-border mergers and acquisitions, firms are driven by the goal of creating value (Xie, Reddy \& Liang, 2017). Successful deals can open new market opportunities for companies and allow them to more effectively leverage their capabilities as well as acquire new ones. At the same time, cross-border transactions involve a high degree of risk, hence associated costs, which managers weigh against opportunities presented by the deal (Chari \& Chang, 2009). Decisions about corporate control represent a major consideration in this process. When entering a new country through mergers and acquisitions, firms can mitigate against the risks associated with engaging with an unfamiliar context by pursuing a higher degree of control in the target company or by sharing the risk with a partner (Kedia \& Bilgili, 2015; Xie et al., 2017). Greater degrees of control generally represent a higher commitment which exposes investors to more risks and limits the extent of investment reversibility. However, it also potentially generates greater value for the acquirer by providing access to organizational knowledge, experience and human capital (Barkema \& Vermeulen, 1998; Erramilli, Agarwal \& Dev, 2002). On the other hand, reducing the degree of control enables investors to share risks with partners and maintain a degree of flexibility to reverse the investment (Ahsan \& Musteen, 2011).

Extant research provides limited reflection on how human rights within a country will impact MNE ownership strategy. Indeed, much of the insights on the role of non-market context considerations and ownership choice come from the work on other non-market issues such as political interference, political risk and corruption. These studies nevertheless offer insights into the non-market context considerations in cross-border investments by suggesting that MNEs adopt a conservative approach to ownership when they are faced with considerable challenges in the non-market environment. For example, starting with Kobrin (1979), research has highlighted the implications of the non-market environment for MNEs' operation and performance. Demirbag and colleagues (2007) have argued that in the context of political risk, MNEs will pursue lower equity stakes in their foreign affiliates. Similarly, Demirbag, McGuinness and Altay (2010) show that perceptions of challenging host country 
ethical and societal issues such as corruption, bribery, business ethics, law and order challenges, including the existence of illegal groups, will lead MNEs to acquire lower stakes in their foreign operations. Research on corruption has produced mixed results, suggesting that arbitrariness, rather than mere prevalence of corruption, is likely to lead to an unpredictable context for investment. Although MNEs may experience additional costs of operating in highly corrupt environments, these settings generally have more predictable rules that enable MNEs to cope with the non-market context, whereas arbitrary corruption is much more difficult to anticipate and therefore to address (Petrou \& Thanos, 2014). For instance, Wei $(1997,2000)$ has argued that pervasiveness of arbitrary corruption in the host environment reduces MNEs' investment in such countries, and Uhlenbruck and colleagues (2006) found that issues stemming from arbitrariness of host country corruption will lead to MNEs sacrificing a higher degree of ownership in a cross-border deal in favor of reducing corruption pressures.

Poor human rights governance, similarly, may serve as another important and distinct source of non-market challenges for foreign investors by directly or indirectly affecting their operations and/or signaling broader governance challenges within the local context. Some of the earlier works theorized that pervasive suppression of human rights, such as collective bargaining, may appear to create predictably stable, thus favorable, conditions for FDI (Blanton \& Blanton, 2007). However, recent evidence suggests that allegations of human rights abuse or condoning human rights violations in countries of operation, have negative implications for MNEs' global activities (Fiaschi et al., 2017). Thanks to the increased level of transparency and speed with which such information now reaches relevant stakeholders - for instance through naming and shaming of complicit companies, and indeed countries, by NGOs (Blanton \& Blanton, 2007) - MNEs are likely to be mindful of poor human rights in some countries and the implications of engaging with such contexts for their global footprint (Fiaschi et al., 2017).

Weak human rights governance implies the need for investors to consider the associated strategic and operational challenges, such as barriers to the use of local human capital and the potential need to put in place policies and procedures to minimize safety hazards (Maitland \& Sammartino, 2015). Further, as an indicator of poor governance, human rights abuses may be a signal or a precursor to 
greater instability which may be caused by the erratic behavior of oppressive governments, or erupt in response to such regimes (Blanton \& Blanton, 2007). For instance, Walsh and Piazza (2010) argue that physical rights abuses by the government incite domestic terrorism by creating tensions among political factions in the country as well as between the government and the general population, but also by undermining the willingness of the international community to collaborate with such states. These factors contribute to daily operational risks and in the long term undermine economic prospects for cross-border operations. Furthermore, firms are increasingly held accountable for allying with repressive governments through silent complicity that involves ignoring human rights abuses and indirectly supporting these regimes by generating revenue through tax payments and investments (Clapham \& Jerbi, 2002; Wettstein, 2010). Such associations can not only tarnish foreign investors' brands but also lead to consumer boycotts and various forms of disruptive backlash that can similarly undermine revenue streams and pose ongoing operational difficulties for MNEs in those countries (Vadlamannati, Janz \& Berntsen, 2018). Preventing civil liabilities in such contexts may involve investing significant resources in enforcing self-regulation and internal human rights commitments.

Additionally, poor human rights governance can create impediments for MNEs to acquire knowledge and skills or integrate their home country activities in their subsidiaries (Ai \& Tan, 2018; Birkinshaw, Bresman \& Nobel, 2010; Kedia, Gaffney \& Clampit, 2012). To facilitate knowledge transfer between headquarters and subsidiaries, host countries would need to be open to immigration and emigration. Free movement of people in and out of the host country (Cingranelli, Richards \& Clay, 2014), for example, can enable tacit knowledge transfer mechanisms by ensuring that expatriates can safely travel between the headquarters and the subsidiary. Tacit knowledge is relevant not only for hightechnology industries where information on technology and skills is exchanged between the parent company and the local unit (Elia \& Santangelo, 2017), but it is also key in service industries where MNEs might be keen to learn customer management in the host country (Zheng, Wei, Zhang \& Yang, 2016). Access to an educated workforce also provides MNEs with opportunities to exploit highly skilled local human capital (Liou, Chao \& Ellstrand, 2017). In this regard, government respect for human rights is salient as it is associated with higher levels of human capital development, which in turn is reflected 
in greater life expectancy and higher levels of education (Blanton \& Blanton, 2007). Finally, clarity in practices regarding labor empowerment and personal freedoms of citizens provides MNEs with clear direction for their integration strategy in the host country, especially while designing their human resource practices to fit with the local context.

Based on the above discussion on the role of non-market environment in ownership decisions, it can be argued that MNEs would aim to acquire higher stakes in countries with better human rights governance, as it would instill greater confidence in investors regarding the predictability of the local context and its ability to support business objectives of MNEs. Accordingly, we put forward the following hypothesis:

Hypothesis 1. The higher the host country's human rights governance, the greater the MNEs' investment in the cross-border targets.

\subsection{Integrating the role of the home country: comparing EMNEs and DMNEs}

To provide a more nuanced perspective on the relationship between MNE strategy and human rights, we also incorporate the role of the home country into our framework (Estrin et al., 2018). Earlier works (Chikhouni et al., 2017; Gammeltoft, Barnard \& Madhok, 2010; Kaynak, Demirbag \& Tatoglu, 2007) have discussed the importance of considering the origin of MNEs in establishing their ownership strategy in foreign operations. Previous studies highlight the differences in the nature of institutional environments that EMNEs and DMNEs face back in their home countries, which in turn contribute to differences in their strategy and internationalization choices (Cuervo-Cazurra \& Genc, 2011; Jormanainen \& Koveshnikov, 2012). For instance, comparative work suggests that bidders from developed economies tend to be more cautious in cross-border deals involving considerable institutional differences than bidders from emerging economies (Gaffney et al., 2016). Cuervo-Cazurra and Genc (2011), on the other hand, explicitly attribute the different stances of DMNEs and EMNEs towards challenges imposed by the non-market environment, to the differences in their home countries' institutional environments. 
MNEs from developed economies are argued to have been socialized into relatively stable institutional contexts, with well-developed formal institutions, including regulation of business conduct (Luo, Zhang \& Bu, 2019), which pressure these firms to continually upgrade their non-market resources (Cuervo-Cazurra \& Genc, 2011). As such, they have been shown to be more likely to opt for higher commitments in contexts characterized by stronger institutional frameworks that promote societal interests (Choi, Lee \& Shoham, 2016). In addition to robust governance, DMNEs' home countries generally have a comparatively more vocal civil society, media and activist consumers who create stringent expectations for corporate conduct (Cuervo-Cazurra \& Genc, 2011). In some cases, these expectations can fully delegitimize the possibility of cooperating with countries whose governments are implicated in human rights abuses. Meyer and Thein (2014), for instance, document how, over the course of the Myanmar crisis, Western MNEs were pressured to leave or reduce their presence in the country. Non-governmental organizations in their domiciles leveraged home-country court systems and the aid of activist investors to put pressure on DMNE decision-makers. Those pressures were also amplified through boycotts organized by home country consumer groups. Similarly, during the 1980s, American companies curbed their operations in South Africa, which at the time was under the apartheid regime (Meznar, Nigh \& Kwok, 1994).

The non-market environment in emerging economies in particular, has been studied as a major factor affecting the internationalization decisions of foreign investors from developed economies into these locations (Luo et al., 2019). For example, DMNEs increasingly consider both operational and reputational costs associated with the local quality of labor standards (Brown, Deardorff \& Stern, 2013). Maggioni and colleagues (2019) show how uneven labor standards drive sub-national location choices of DMNEs in Turkey. They propose that in developing market settings, the prevalence of informal institutions, uneven economic development, and weak regulations result in different degrees of unionization within the country. In such contexts, industrial relations would be underpinned by informal norms that may be difficult and costly to learn for outsiders, with strong unions deterring foreign firms from sectors with less reversibility. Elsewhere, scholars have also shown that DMNEs struggle to deal with less predictable political environments. Morck and colleagues (2008) documented the challenges 
faced by a Canadian-owned firm in Kazakhstan which eventually left the country, unable to manage the threat of expropriation. Some researchers have also shown that legal and normative restrictions in home countries may constrain DMNEs' ability to commit to settings characterized by non-market hazards, such as corruption (Tekin-Koru, 2006).

Home country institutions of EMNEs, on the other hand, allow these firms to develop a certain set of non-market capabilities that puts them in a particularly strong position to deal with turbulent and risky settings (Morck et al., 2008) vis-à-vis DMNEs who emerge from more institutionally robust environments, by either developing the necessary resources without institutional support or learning to operate in their absence (Cuervo-Cazurra \& Genc, 2011; Madhok \& Keyhani, 2012; Ramamurti, 2012). Although this effect may not equally extend to all areas of local governance failure (Cuervo-Cazurra \& Genc, 2008), EMNEs have been theorized to be comparatively less deterred by corruption, political instability or low government effectiveness, as they may have learned to manage these issues at home (Malhotra et al., 2016). Rabellotti (2014), for instance, points out that EMNEs from China have a propensity to invest in countries with weak institutions. Similarly, Habib and Zurawicki (2002) argue that MNEs' engagement with weaker non-market environments, such as corruption, provides them with a learning opportunity which later enables them to handle equally challenging issues in other weaker institutional environments.

Prior studies also suggest that EMNEs are attracted to contexts characterized by well-developed market institutions (Chari \& Shaikh, 2017; Xie et al., 2017). Since they lack the ownership advantages possessed by DMNEs (Ramamurti, 2012), in their international expansion EMNEs are compelled by competitive pressures, limited prospects for growth in their domestic markets (Aulakh, 2007) and the need to catch up with their developed-market counterparts (Luo \& Tung, 2007). Higher equity participation in targets based in these settings provides EMNEs with opportunities to rapidly access local competencies and knowledge (Gaffney et al., 2016). For example, in the absence of a strong rule of law at home, EMNEs have been compelled to invest heavily in markets with robust property rights enforcement and transparent business regulations (Chittoor, Sarkar, Ray \& Aulakh, 2009; CuervoCazurra, Alvaro, Ramamurti, 2015). For instance, Deng and Yang (2015) find that more robust 
governance attracts a larger number of acquisitions from emerging market investors. Liou and colleagues (2016) observe that EMNEs will seek higher ownership in foreign targets located in countries with substantially more advanced economies, which are also associated with well-developed institutions. Demirbag and co-authors' (2009) study of Turkish MNEs demonstrates that investments in developed economies will attract higher ownership in the target companies.

Yet, research has shown that despite their aggressive acquisition strategies and attraction to well-developed institutions, EMNEs do face difficulties in such contexts, particularly in the non-market domain, stemming at least in part from their lack of experience with more stringent institutional environments, which would enable them to develop more sophisticated non-market resources and capabilities (Child \& Marinova, 2014). For instance, unlike their developed-marked counterparts, EM firms are not always prepared to deal with strong labor rights in host countries, although they may attempt to address integration challenges post-entry (Khan, Wood, Tarba, Rao-Nicholson \& He, 2018). Zhu, Zhu, and De Cieri (2014) found that Chinese firms fail to consider labor issues when expanding into advanced economies, prompting them to face challenges in these settings. Tellingly, Brazil's Vale struggled with a union dispute when workers of Canadian Inco, its first major international acquisition, challenged the new owner's compensation practices (Financial Times, 2010). Whereas DMNEs may have developed self-regulation in the form of codes of ethical conduct and corporate social responsibility which may reflect the expectations of contexts with more robust human rights governance, these practices are still relatively new to EMNEs (Marano, Tashman \& Kostova, 2017). Thus, whilst there is evidence suggesting that EMNEs are attracted to good governance, particularly reflected in formal market-supporting institutions, the challenges that a more robust non-market environment imposes on these firms may temper their aspirations.

Although systematic comparative work on non-market institutions and internationalization strategies of DMNEs and EMNEs is limited (Xie et al., 2017), the above discussion provides indicative insights into their differences. In one of the few studies to explicitly employ such comparisons, Malhotra and colleagues (2010) compared the effects of host country corruption of cross-border deals of firms from China and the United States. Their findings show that although firms from both countries conduct 
more deals in less corrupt markets, Chinese firms pursue greater commitment, reflected in deal value, in more corrupt economies. The authors reason that Chinese firms may require less effort to adapt to operating in such settings - indeed, commitment in those countries may for them represent a more favorable strategy of creating value from cross-border deals. In sum, we would expect EMNEs to be more adept than DMNEs at managing non-market uncertainty, such as that stemming from weak human rights governance in host countries.

Therefore, we propose:

Hypothesis 2. The effect of host country human rights governance on the MNEs' investment in the crossborder targets will be weaker for EMNEs than for DMNEs.

[insert Figure 1 about here]

\section{Methods and Data}

\subsection{Sample and data collection}

This study focuses on fourteen large and small emerging economies, namely, Argentina, Brazil, India, China, Russia, South Africa, Indonesia, Poland, Turkey, Mexico, Thailand, Malaysia, United Arab Emirates and Chile, as deals from these countries have accounted for more than quarter of the global cross-border deals in recent years (UNCTAD, 2014). The data for this study was collected from SDC Platinum, which is provided by Thomson Reuters Financial Securities Data and consists of all completed deals conducted between 1995 and 2010. To exclude portfolio investments, following prior literature, we removed deals where the acquirers had taken less than $10 \%$ of the overall share in the target company (Liou et al., 2016). The deals without information on the deal value and ownership stakes were removed from the initial sample.

\subsection{Creation of a matched sample}

The matched sample procedure was chosen instead of considering all developed market deals as including all developed market deals would greatly bias the final sample since there are more deals from the developed countries as a whole (Nicholson \& Salaber, 2013). Therefore, in this case, creating a matched sample provides a more efficient way of testing our hypothesis. We used US deals to proxy 
developed market deals since the US is one of the most dynamic and active markets for mergers and acquisitions, including cross-border deals (Malhotra et al., 2016). For each emerging market deal in our sample, we located a US deal according to the following criteria. Firstly, the host country for the US deal needed to be the same as that of the emerging market deal, since host country conditions are the focus of this study. Secondly, we find the deals that occurred in the same announcement period, i.e., the one-year range around the announcement date. Thirdly, we match the remaining deals within the same bidder industry. Next, deals are gathered from the smallest difference in the deal value of both bidding firms. Our matching process revealed that US firms did not necessarily acquire in the same locations and industry during the same period as the emerging market companies, and we have 79 target destinations in the matched sample. Thus, along with accounting for missing values and unmatched deals, the sample was reduced to 2802 deals, where 1401 deals belonged to developed countries. The average values were close for both sub-samples indicating a good match between our samples: deal value (\$198 million for emerging market companies and \$199 million for developed market companies respectively) and past experience ( 0.49 and 0.39 respectively). The detail on the sampled acquirers and targets engaged in cross-border deals is presented in Table 1.

[insert Table 1 about here]

\subsection{Dependent variable}

Ownership level, the dependent variable, consists of the equity stake that the acquirer has in the target firm after the acquisition. Table 2 provides details on the variables used in this study, and their measurement.

[insert Table 2 about here]

\subsection{Independent variable}

The data on human rights protection within a host country is obtained from Cingranelli, Richards and Clay (2014). These include the Physical integrity rights index and Empowerment rights index. The Physical integrity rights index and Empowerment rights index were also added together to obtain a cumulative index for human rights within a country. The Physical integrity rights index is an 
additive index consisting of four elements: Torture, Extrajudicial Killings, Political Imprisonments, and Disappearances (Cingranelli \& Richards, 1999). The Torture indicator measures the level of government-sanctioned mental and physical abuse, either initiated by the government or by private individuals. The Political Imprisonments indicator measures the level of incarceration of people due to their speech and non-violent opposition to governmental policies and leaders. The Extrajudicial Killings indicator measures the killings without the due process of the country's laws initiated by the government officials. Finally, the Disappearances indicator measures the level of disappearances within a state that is politically motivated. The four indicators take values between 0 (frequent occurrences), 1 (occasional occurrences), and 2 (no occurrences).

In turn, the host country's Empowerment rights index consists of seven indicators: Foreign Movement, Domestic Movement, Freedom of Speech, Freedom of Assembly and Association, Workers' Rights, Electoral Self-Determination, and Freedom of Religion (Richards et al., 2001). Foreign and Domestic Movement indicators measure the level of freedom for people to leave and enter their country and overall freedom of travel within their country. The Freedom of Speech index measures the degree of government censorship within a country, whereas, the Electoral Self-Determination index measures the extent to which the citizens enjoy political and electoral freedom. The Freedom of Assembly and Association is an overarching freedom index that looks at the level of liberty in a country regarding people's rights to gather and engage in political and non-political activities. The index related to Workers' Rights captures the degree of freedom for employees to organize themselves and participate in collective bargaining. Finally, the Freedom of Religion captures the extent to which the state protects citizens' freedom of religion. This index takes values between 0 (no government protection for the seven rights reflected in the indicators) to 14 (full government support for the seven rights).

\subsection{Control variables}

Formal institutional distance is obtained from the Heritage Foundation and consists of the Index for Economic Freedom, which has been extensively used in extant studies to measure distances between the formal institutions in the home and host countries (Aybar \& Ficici, 2009; Liou et al., 2016). To obtain the formal institutional distance, the Index for Economic Freedom score of the home country 
is subtracted from the Index of Economic Freedom score of the host country. For EMNEs' acquisitions in the developed markets, this value will be positive, whereas it will be negative when buying in developing countries.

The Cultural distance variable used in this study to control for any other social and normative factors has been widely employed to control for cultural issues in cross-border acquisitions (Ang et al., 2015; Gaur, Delios \& Singh, 2007; Nicholson \& Salaber, 2013). In the main results, Hofstede's methodology for assessing cultural values that were used in prior studies to measure the cultural distance between the two countries, was employed (Kogut \& Singh, 1988; Nicholson \& Salaber, 2013). This approach produces a score to indicate the absolute cultural difference between the host and home countries.

Along with cultural distance between the two countries, we also control for several deal-, firmand country-level characteristics. We control for industry relatedness of deals: Same industry is a dummy variable that takes value 1 when both the acquirer and the target belong to the same industry (Liou, Rao-Nicholson \& Sarpong, 2018). Extant works (Denis, Denis \& Yost, 2002; Moeller \& Schlingemann, 2005; Shleifer \& Vishny, 2003) have highlighted the consolidation effects in acquisitions, and we control for this effect using a dummy variable. Deal value is the log value of the transaction (Gubbi, Aulakh, Ray, Sarkar \& Chittoor, 2010; Moeller \& Schlingemann, 2005). Cash variable indicates the payment method and takes value 1 if the acquisition was conducted through cash (and not equity) transfer. The payment mechanism has been noted to influence ownership stakes (King, Dalton, Daily \& Covin, 2004; Lahiri, Elango \& Kundu, 2014; Liou \& Rao-Nicholson, 2017).

Also, the acquirer's past acquisition experience will impact their future acquisition strategy as they will be better able to anticipate and manage risks in international transactions (Lahiri et al., 2014; Liou et al., 2016). We control for this effect by including the variable Past experience in our model. We control for several country-level effects in our empirical model. The economic distance between the two countries, measured by the difference in their respective GDP per capita (GDP distance), is used to control for effects of differences in the level of economic development (Liou et al., 2018). Studies have suggested that minority shareholder protection in the host country can determine the 
governance structure in cross-border deals and promote acquirers to claim full control during the acquisitions (Ferreira, Massa \& Matos, 2010). Equally, minority shareholder protection can promote and enable the development of various supporting institutions in the country (Guillén \& Capron, 2016). We create a Minority shareholder protection (HOST) variable which indicates the level of minority shareholder protection in the country (Guillén \& Capron, 2016).

We also control for the level of inward foreign direct investment (Inward foreign direct investment) in the host country as it might impel acquirers to gain a larger share in the targets to prevent their competitors from potentially mounting a hostile takeover or gaining access by exploiting low entry barriers (Kogut \& Chang, 1991). Lastly, we control for various industry effects, country differences and year effects by including dummies for different sectors, countries and years. The industry dummies are created per the first two digits of the acquiring firms' industry codes (Brouthers \& Brouthers, 2003).

The descriptive statistics and correlation analysis of the dependent, independent, moderator and control variables are given in Table 2. Due to high levels of correlation between the two main variables, we do not use them in the same empirical model, and hence, our hypotheses are tested independently of the other factors utilized in this study. Following the initial analysis, we created the composite variable for human rights to test for the combined effects of their various individual elements. The data sources and variable descriptions are outlined in Table 3.

\section{[insert Table 3 about here]}

\subsection{Model and analysis}

The Tobit regression is used in the empirical analysis (Chari \& Chang, 2009; Liou et al., 2016) due to the censored nature of our data as the stakes in the acquired companies range between $10-100 \%$, and this method provides accurate estimates (Cuypers \& Martin, 2010). Also, deals belonging to the same firm were clustered together using the cluster option in STATA software (Chari \& Chang, 2009; Liou et al., 2016). The empirical model used in this study consists of the following variables: $Y n$, the dependent variable, $X i$, the independent variable measuring the human rights value in the host country and $C k$, which is the set of control variables. The empirical model, in general form, is shown below: 
$Y n=\beta o+\sum \beta i X i+\sum \beta k C k+E$

Each empirical model with a single moderating factor and interaction term generates variance inflation factor (VIF) between 1-3, which are much below the accepted levels of 10 or above and which indicates the multicollinearity problems (Hair, Anderson, Tatham \& Black, 1998).

\section{Results}

Table 4 presents the results of our analysis. Columns 1-3 present the main results, and Columns 4-9 present the results of our robustness analysis. The result in Column 1 presents the baseline analysis. The result in Column 2 shows the estimates for our first human rights index, namely, the Physical integrity rights index, and we observe that this estimate is positive and significant $(\beta=0.678, \mathrm{p}>0.1)$. The result in Column 3 shows the estimates for our second human rights index, namely, the Empowerment rights index, and we observe that this estimate is positive though not significant. This supports Hypothesis 1. Similarly, the estimates presented in Column 4, which consists of a cumulative value for the human rights index, is positive but not significant, and we observe that the result for our human rights index obtained by principal component analysis is positive and significant.

Next, we conduct two separate analyses for ownership measures. First, we use two levels for ownership, namely majority or not, and use Probit analysis to draw our estimates. We observe that our estimates presented in Columns 6-7 are similar to those presented as our main results. The second analysis consists of three ordered levels of ownership, full ownership, majority ownership and minority ownership, and we use an ordered Probit model to determine our estimates. The results obtained in Columns 8-9 show that these estimates for the human rights index are similar to those presented as our main results.

[insert Table 4 and 5 about here]

Table 5 presents the results of our further robustness tests. In this case, we use two alternative measures of institutional distance, namely the financial distance and the property rights distance. We observe that the results of these robustness tests are similar to those presented in our main table. Furthermore, we conducted analysis with a control for ownership restriction, which has been recognized 
among the factors influencing foreign ownership decisions (Kedia \& Bilgili, 2015), where this was proxied by an indicator on Business Freedom from Economic Freedom Index, and our results were similar to those presented in this paper.

We used another measure for ownership restriction for which we obtained data from the World Bank. The World Bank provides aggregated information for ownership restrictions within a country where data is available at SIC 1-digit level (for example, Agriculture, Mining, Oil and Gas, and so on), and the data shows the Foreign ownership allowed in this aggregated sector, for example, in the Agriculture sector in the US it is $100 \%$. This leads us to calculate the Ownership restriction measure as equal to 100 minus Foreign ownership allowed, and in the US Agriculture, it would be zero. We observed that with most countries there are few sectors which have restriction on ownership like Energy and Mining. The ownership restriction data is available for the year 2009, and given that we have data from 2000-2010 in this study, we conducted a sub-sample analysis using data for 2009-2010 and employing the Ownership restriction as a control in this model. The results of this analysis, which included 696 observations, are similar to those presented in the main analysis.

Amongst our control variables, we observe that some of these are significant in various models. Formal institutional distance is negative and significant in some of our models, and in others, cultural distance is negative and significant. The Same industry control variable is positive and significant in most of our models, suggesting a strong result for the consolidation effect in our analysis. This result suggests that MNEs are greatly influenced by consolidation strategies and acquire higher stakes when they target deals in their own industries. The Deal value has positive and significant value in all our models, thus suggesting a strong result for this variable in our study. This result indicates that the higher the deal value, the more likely the MNEs are to acquire a greater stake in their target. One rationale for this result could be that in deals with greater investment, MNEs are keen to gain a higher stake in their target to take ownership of the strategy process. Similarly, GDP distance is likely to lead to higher ownership. The Past experience, too, will indicate this ownership approach by MNEs. The levels of Minority shareholder protection (HOST) will lead to lower ownership by MNEs. Lastly, the inward 
foreign direct investment will lead to MNEs acquiring higher stakes in their target, indicating further support to consolidation, especially global, for these firms.

Next, we conduct the analysis of our matched sample. We adopt the approach presented in Estrin et al. (2018), where the authors present a sub-sample analysis (firms from developed versus emerging markets) as well as a full model where the emerging market effect is demonstrated as an interaction effect. We observe that the coefficients for human rights indices are positive for both developed and emerging market firms, and in absolute values, the coefficient for developed markets is higher than that for emerging markets. The test of the difference of coefficients X2 reveals that differences in both human rights indices are significant at $1 \%(\mathrm{p}=0.000)$. Hypothesis 2 can also be tested by considering the sign and significance of the coefficient on the Emerging market $\mathrm{x}$ Physical integrity rights index and Emerging market $\mathrm{x}$ Empowerment rights index in the combined full model in Columns 5 and 6 , respectively. It can be seen that the coefficient is negative and significant at the $1 \%$ level $(\mathrm{p}=0.000)$, indicating that physical integrity rights index and empowerment rights index effects are significantly smaller in the emerging market sub-sample. This further supports Hypothesis 2.

[insert Table 6 and 7 about here]

\section{Discussion}

Although the recognition of the role of the non-market environment for MNE activities has long been a major theme in international business research, recent years have seen a particular interest in expanding on its implications. As Voinea and Kranenburg argue (2008: 730), “[d]espite managerial and academic acknowledgment of the importance of nonmarket institutions...their impacts on MNE behavior remain ambiguous". This call is echoed by De Villa and colleagues (2015: 424) who suggest that it is particularly useful "to explore the non-market institutions... and their implications for market entry choices." Motivated by recent debates on the relationship between international business and human rights, in this paper, we set out to contribute to this growing literature by examining whether human rights governance in the host country, as one underexplored dimension of the non-market environment, affects cross-border ownership strategies of MNEs. We conceptualized espoused host country human rights practices as sources of risk to MNEs' global aspirations and a source of challenges 
resulting from direct and indirect potential consequences to MNE operations. Our findings suggest that human rights governance has significant effects on ownership choices for MNEs, and that it matters comparatively more to DMNEs than EMNEs. We now turn to the key theoretical contributions of our study.

We make our main theoretical contribution to the literature on non-market environment and its impact on strategic choices by MNEs (Doh \& Lucea, 2013; Rodriguez et al., 2006; Uhlenbruck et al., 2006; Maggioni et al., 2019), specifically the role of human rights regimes in host contexts. Slangen and van Tulder (2009) suggested that scholars need to measure the uncertainty embedded in the host country's overall governance infrastructure, including its most important dimensions such as government effectiveness, regulatory quality and control of corruption, and call for advancement of "our understanding of the role that governance dimensions other than political risk play in MNEs' foreign entry strategies" (p.288). In this study, we demonstrate that it is indeed pertinent to examine the specific characteristics of the host country's non-market environment for MNE strategy, in addition to the implications, cultural and regulatory differences between home and host settings.

With regard to human rights specifically, previous research on MNEs has considered them as a subset of regulatory institutions and/or democratic governance (Ang et al., 2015), whereas our approach is distinguished by considering human rights as realized in societal practices espoused by the state. Although we have drawn on extant research on MNEs' non-market environment, which has to a large extent focused on issues of political risk and corruption, these institutional factors may affect investors' perceptions of host country challenges distinctly from human rights governance. For instance, while human rights issues may be indicative of wider governance failures, policy risk is common to functioning democracies (Jensen, 2008). We therefore argue and demonstrate empirically that investment commitments of MNEs from both emerging and developed economies are likely to be affected by human rights governance considerations. It is indeed possible to argue that although foreign investors may with time learn to operate and even lobby home-country governments to relax restrictions on investment in settings characterized by pervasive corruption (Tekin-Koru, 2006), poor human rights governance represents a distinct set of substantive operational risks and considerably grave concerns 
about the viability of leveraging the value of cross-border deals in these settings, and as an indicator of potentially wider systemic failure causes MNEs to consider their host country commitments with greater caution.

Prior work has acknowledged that MNE home country influence contributes significantly to firm strategy, particularly in relation to non-market institutions (Puck et al., 2018). By comparing ownership strategies and governance considerations of MNEs from developed and emerging economies, our paper also contributes to the calls to compare international expansion strategies of DMNEs and EMNEs (Cuervo-Cazurra, 2012; Malhotra et al., 2016). An ongoing debate in the international business literature concerns whether EMNEs are similar to, or sufficiently distinct from, DMNEs to warrant novel theoretical frameworks that explain their strategies (Buckley et al., 2018; Hernandez \& Guillén, 2018). Despite persistent theoretical questioning, however, comparative studies of EMNEs and DMNEs' cross-border strategies have been rare and primarily focused on the implications of the host country market context (see Estrin et al., 2018; Xie et al., 2017). Employing a matched sample analysis of deals by the two groups of investors, we also extend the comparative work of scholars such as Malhotra and colleagues (2010). Our results lend support to the argument that EMNEs do differ in their internationalization strategies from DMNEs and suggest the need for a more nuanced and integrated perspective on the role of their home country contexts, the non-market capabilities that they help foster and the implications for these firms' strategic choices in host countries (Cuervo-Cazurra \& Genc, 2008; Cuervo-Cazurra \& Genc, 2011).

An important nuance of our findings, however, is that although EM investors are less sensitive to human rights governance in host countries, these issues nevertheless do have a significant impact on their cross-border deals. According to Giuliani and colleagues (2016, p. 635), the "key concern connected to the HR [human rights] conduct of EMNEs comes from considering the country of origin of these new players." Yet, human rights are a highly politically sensitive and visible issue for companies and their stakeholders alike. Fiaschi and colleagues (2017) found that as EMNEs expand, they face heightened scrutiny and pressures to avoid human rights-related scandals. Our results, based on the data from EMNEs headquartered in fourteen countries, support this view and suggest that despite 
various critiques and limitations imposed by their home-country weaknesses, there is indeed a "business case" for human rights respect (Blanton \& Blanton, 2007; Vogel, 2005) from EMNE managers' perspective. Although EMNEs appear to be less deterred by risks, as some of the extant works suggest (Buckley et al., 2018; Li, Quan, Stoian \& Azar, 2018; Quer, Claver \& Rienda, 2012), over time, through the process of internationalization we might expect these firms to become exposed to more societal expectations and to develop a more cautious approach to non-market risks.

Despite our contributions, we are aware of several limitations which nevertheless open up exciting avenues for future research. First, due to the availability of data on human rights, we consider deals that took place between 1995 and 2011. Although the rapid growth of FDI from emerging markets is captured in this period (Fiaschi et al., 2017), we would encourage scholars to extend our analysis in future work as updated datasets become available. Second, we compared EMNEs with DMNEs from a single country. This approach has been used in previous studies (Malhotra et al., 2016; Xie et al., 2017). EMNE expansion is still in relatively early stages and this allows us to mitigate the disparity in the general number of acquisitions conducted by these firms and DMNEs. However, future work could extend this analysis to MNEs from other developed home countries. A framework drawing on comparative institutionalism (Fainshmidt, Judge, Aguilera \& Smith, 2018; Jackson \& Deeg, 2008) could be applied to multiple combinations of emerging and developed countries, as prior research has shown differences in stakeholder expectations for corporate responsibility and human rights respect (Rathert, 2016). Third, human rights represent an important facet of the host country institutional environment, but future research should also examine how these interact with other dimensions of governance. Fourth, future work could develop our findings further by investigating how different investment motives, such as strategic asset-seeking or natural resource-seeking, may impact the relationship between human rights and ownership propensity. The limitations of the data availability make it difficult to distinguish the type of investment in this study. Fifth, this study considers the host country human rights level and its influence on DMNEs' and EMNEs' strategies, and building on the framework and data sources employed in this research, future work can look at the distance between human rights in MNEs' home and host countries. Similarly, studies can take a nuanced view of human 
rights issues and assess the fine-grained effects of specific human rights issues in the host country. For example, human rights indicators in our study are made of several sub-indicators, and it would be interesting to examine which aspects matter relatively more to MNEs. Finally, guided by our aims, we selected a quantitative approach which, nevertheless, opens up a number of questions that need to be addressed through qualitative research. A fruitful way forward would involve interviewing MNE managers about human rights due diligence, now increasingly carried out during mergers and acquisitions, to examine how host country human rights governance might interact with corporate selfregulation and the implications these interactions have for managerial decision-making.

From a practical standpoint, our study also has implications for managers and policymakers. How corporations make investment decisions has important implications for home and host societies. Our findings suggest that robust human rights governance is attractive to investors from both developed and emerging markets. For policymakers, it might be particularly important to work with the civil society responsible for "spotlighting" different human rights regimes (Barry, Clay \& Flynn, 2013) to ensure that investors are more acutely aware of the extent of human rights respect in potential destination countries. 


\section{REFERENCES:}

Ahsan, M., \& Musteen, M. (2011). Multinational enterprises' entry mode strategies and uncertainty: A review and extension. International Journal of Management Reviews, 13(4), 376-392. https://doi.org/10.1111/j.1468-2370.2010.00296.x

Ai, Q., \& Tan, H. (2018). The intra-firm knowledge transfer in the outward M\&A of EMNCs: Evidence from Chinese manufacturing firms. Asia Pacific Journal of Management, 35(2), 399425. https://doi.org/10.1007/s10490-017-9518-z

Anderson, E., \& Gatignon, H. (1986). Modes of foreign entry: A transaction cost analysis and propositions. Journal of International Business Studies, 17(3), 1-26. https://doi.org/10.1057/palgrave.jibs.8490432

Ang, S. H., Benischke, M. H., \& Doh, J. P. (2015). The interactions of institutions on foreign market entry mode. Strategic Management Journal, 36(10), 1536-1553. https://doi.org/10.1002/smj.2295

Arregle, J.-L., Miller, T. L., Hitt, M. A., \& Beamish, P. W. (2013). Do regions matter? An integrated institutional and semiglobalization perspective on the internationalization of MNEs. Strategic Management Journal, 34(8), 910-934. https://doi.org/10.1002/smj.2051

Aulakh, P. S. (2007). Emerging multinationals from developing economies: Motivations, paths and performance. Journal of International Management, 13(3), 235-240.

https://doi.org/10.1016/j.intman.2007.05.001

Aybar, B., \& Ficici, A. (2009). Cross-border acquisitions and firm value: An analysis of emergingmarket multinationals. Journal of International Business Studies, 40(8), 1317-1338. https://doi.org/10.1057/jibs.2009.15

Barkema, H. G., \& Vermeulen, F. (1998). International expansion through start-up or acquisition: A learning perspective. Academy of Management Journal, 41(1), 7-26. https://doi.org/10.2307/256894

Baron, D. P. (1995). Integrated strategy: Market and nonmarket components. California Management Review, 37(2), 47-65. https://doi.org/10.2307/41165788

Barry, C. M., Chad Clay, K., \& Flynn, M. E. (2013). Avoiding the spotlight: Human rights shaming and foreign direct investment. International Studies Quarterly, 57(3), 532-544. https://doi.org/10.1111/isqu.12039

Birkinshaw, J., Bresman, H., \& Nobel, R. (2010). Knowledge transfer in international acquisitions: A retrospective. Journal of International Business Studies, 41(1), 21-26. https://doi.org/10.1057/jibs.2009.71

Blanton, S. L., \& Blanton, R. G. (2007). What attracts foreign investors? An examination of human rights and foreign direct investment. The Journal of Politics, 69(1), 143-155. https://doi.org/10.1111/j.1468-2508.2007.00500.x

Brouthers, K. D., \& Brouthers, L. E. (2003). Why service and manufacturing entry mode choices differ: The influence of transaction cost factors, risk and trust. Journal of Management Studies. https://doi.org/10.1111/1467-6486.00376

Brown, D. K., Deardorff, A. V, \& Stern, R. M. (2013). Labor standards and human rights: Implications for international trade and investment (pp. 153-195). https://doi.org/10.1142/9789814390842_0005

Buckley, P. J. (2018). Internalisation theory and outward direct investment by emerging market multinationals. Management International Review. https://doi.org/10.1007/s11575-017-0320-4 
Buckley, P. J., Clegg, L. J., Voss, H., Cross, A. R., Liu, X., \& Zheng, P. (2018). A retrospective and agenda for future research on Chinese outward foreign direct investment. Journal of International Business Studies, 49(1), 4-23. https://doi.org/10.1057/s41267-017-0129-1

Chari, M. D., \& Chang, K. (2009). Determinants of the share of equity sought in cross-border acquisitions. Journal of International Business Studies, 40(8), 1277-1297. https://doi.org/10.1057/jibs.2008.103

Chari, M. D. R., \& Shaikh, I. A. (2017). Defying distance? Cross-border acquisitions by emergingeconomy firms. Thunderbird International Business Review, 59(2), 173-186. https://doi.org/10.1002/tie.21823

Chikhouni, A., Edwards, G., \& Farashahi, M. (2017). Psychic distance and ownership in acquisitions: Direction matters. Journal of International Management, 23(1), 32-42. https://doi.org/10.1016/j.intman.2016.07.003

Child, J., \& Marinova, S. (2014). The role of contextual combinations in the globalization of chinese firms. Management and Organization Review, 10(3), 347-371. https://doi.org/10.1111/more.12073

Chittoor, R., Sarkar, M., Ray, S., \& Aulakh, P. S. (2009). Third-world copycats to emerging multinationals: Institutional changes and organizational transformation in the Indian pharmaceutical industry. Organization Science, 20(1), 187-205. https://doi.org/10.1287/orsc.1080.0377

Choi, J. J., Lee, S. M., \& Shoham, A. (2016). The effects of institutional distance on FDI inflow: General environmental institutions (GEI) versus minority investor protection institutions (MIP). International Business Review, 25(1), 114-123. https://doi.org/10.1016/j.ibusrev.2014.11.010

Cingranelli, D., Richards, D., \& Clay, K. (2014). The CIRI Human Rights Dataset. Retrieved from http://www.humanrightsdata.com

Cingranelli, D. L., \& Richards, D. L. (1999). Measuring the level, pattern, and sequence of government respect for physical integrity rights. International Studies Quarterly, 43(2), 407417. https://doi.org/10.1111/0020-8833.00126

Cingranelli, D. L., \& Richards, D. L. (2010). The Cingranelli and Richards (CIRI) Human Rights Data Project. Human Rights Quarterly, 32(2), 401-424. https://doi.org/10.1353/hrq.0.0141

Clapham, A., \& Jerbi, S. (2002). Categories of corporate complicity in human rights abuses. Hastings International and Comparative Law Review, 24, 339-349.

Collins, J. D., Uhlenbruck, K., \& Rodriguez, P. (2009). Why firms engage in corruption: A top management perspective. Journal of Business Ethics, 87(1), 89-108. https://doi.org/10.1007/s10551-008-9872-3

Cuervo-Cazurra, Alvaro, Ramamurti, R. (2015). The escape motivation of emerging market multinational enterprises. Columbia FDI Perspectives, 143.

Cuervo-Cazurra, A. (2006). Who cares about corruption? Journal of International Business Studies, 37(6), 807-822. https://doi.org/10.1057/palgrave.jibs.8400223

Cuervo-Cazurra, A. (2012). Extending theory by analyzing developing country multinational companies: Solving the Goldilocks debate. Global Strategy Journal, 2(3), 153-167. https://doi.org/10.1111/j.2042-5805.2012.01039.x

Cuervo-Cazurra, A., \& Genc, M. (2008). Transforming disadvantages into advantages: developingcountry MNEs in the least developed countries. Journal of International Business Studies, 39(6), 957-979. https://doi.org/10.1057/palgrave.jibs.8400390

Cuervo-Cazurra, A., \& Genc, M. E. (2011). Obligating, pressuring, and supporting dimensions of the 
environment and the non-market advantages of developing-country multinational companies. Journal of Management Studies, 48(2), 441-455. https://doi.org/10.1111/j.14676486.2010.00964.x

Cuervo-Cazurra, A., Luo, Y., Ramamurti, R., \& Ang, S. H. (2018). The impact of the home country on internationalization. Journal of World Business, 53(5), 593-604. https://doi.org/10.1016/j.jwb.2018.06.002

Cuypers, I. R., \& Martin, X. (2010). What makes and what does not make a real option? A study of equity shares in international joint ventures. Journal of International Business Studies, 41(1), 47-69. https://doi.org/10.1057/jibs.2009.17

De Villa, M. A., Rajwani, T., \& Lawton, T. (2015). Market entry modes in a multipolar world: Untangling the moderating effect of the political environment. International Business Review, 24(3), 419-429. https://doi.org/10.1016/j.ibusrev.2014.10.001

Delios, A., \& Henisz, W. J. (2003). Political hazards, experience, and sequential entry strategies: the international expansion of Japanese firms, 1980-1998. Strategic Management Journal, 24(11), 1153-1164. https://doi.org/10.1002/smj.355

Demirbag, M., Glaister, K. W., \& Tatoglu, E. (2007). Institutional and transaction cost influences on MNEs' ownership strategies of their affiliates: Evidence from an emerging market. Journal of World Business, 42(4), 418-434. https://doi.org/10.1016/j.jwb.2007.06.004

Demirbag, M., McGuinness, M., \& Altay, H. (2010). Perceptions of institutional environment and entry mode. Management International Review, 50(2), 207-240. https://doi.org/10.1007/s11575010-0028-1

Demirbag, M., Tatoglu, E., \& Glaister, K. W. (2009). Equity-based entry modes of emerging country multinationals: Lessons from Turkey. Journal of World Business, 44(4), 445-462. https://doi.org/10.1016/j.jwb.2008.11.009

Deng, P., \& Yang, M. (2015). Cross-border mergers and acquisitions by emerging market firms: A comparative investigation. International Business Review, 24(1), 157-172. https://doi.org/10.1016/j.ibusrev.2014.07.005

Denis, D. J., Denis, D. K., \& Yost, K. (2002). Global diversification, industrial diversification, and firm value. The Journal of Finance, 57(5), 1951-1979. https://doi.org/10.1111/0022-1082.00485

Di Guardo, M. C., Marrocu, E., \& Paci, R. (2016). The effect of local corruption on ownership strategy in cross-border mergers and acquisitions. Journal of Business Research, 69(10), 42254241. https://doi.org/10.1016/j.jbusres.2016.03.002

Doh, J. P., \& Lucea, R. (2013). So close yet so far: Integrating global strategy and nonmarket research. Global Strategy Journal, 3(2), 171-194. https://doi.org/10.1111/j.20425805.2013.01053.x

Duanmu, J.-L. (2011). The effect of corruption distance and market orientation on the ownership choice of MNEs: Evidence from China. Journal of International Management, 17(2), 162-174. https://doi.org/10.1016/j.intman.2011.01.003

Elia, S., \& Santangelo, G. D. (2017). The evolution of strategic asset-seeking acquisitions by emerging market multinationals. International Business Review, 26(5), 855-866. https://doi.org/10.1016/j.ibusrev.2017.02.004

Estrin, S., Meyer, K. E., \& Pelletier, A. (2018). Emerging economy MNEs: How does home country munificence matter? Journal of World Business, 53(4), 514-528. https://doi.org/10.1016/j.jwb.2018.02.004

Fainshmidt, S., Judge, W. Q., Aguilera, R. V., \& Smith, A. (2018). Varieties of institutional systems: 
A contextual taxonomy of understudied countries. Journal of World Business, 53(3), 307-322. https://doi.org/10.1016/j.jwb.2016.05.003

Ferreira, M. A., Massa, M., \& Matos, P. (2010). Shareholders at the gate? Institutional investors and cross-border mergers and acquisitions. Review of Financial Studies, 23(2), 601-644. https://doi.org/10.1093/rfs/hhp070

Fiaschi, D., Giuliani, E., \& Nieri, F. (2017). Overcoming the liability of origin by doing no-harm: Emerging country firms' social irresponsibility as they go global. Journal of World Business, 52(4), 546-563. https://doi.org/10.1016/j.jwb.2016.09.001

Financial Times. (2010, May 7). Vale in Canadian strike deal. Financial Times. Retrieved from https://www.ft.com/content/ffd7c2d2-87d4-11df-9f37-00144feabdc0

Gaffney, N., Karst, R., \& Clampit, J. (2016). Emerging market MNE cross-border acquisition equity participation: The role of economic and knowledge distance. International Business Review, 25(1), 267-275. https://doi.org/10.1016/j.ibusrev.2015.05.005

Gammeltoft, P., Barnard, H., \& Madhok, A. (2010). Emerging multinationals, emerging theory: Macro- and micro-level perspectives. Journal of International Management, 16(2), 95-101. https://doi.org/10.1016/j.intman.2010.03.001

Garriga, A. C. (2016). Human rights regimes, reputation, and foreign direct investment. International Studies Quarterly, 60(1), 160-172. https://doi.org/10.1093/isq/sqw006

Gaur, A. S., Delios, A., \& Singh, K. (2007). Institutional environments, staffing strategies, and subsidiary performance. Journal of Management, 33(4), 611-636. https://doi.org/10.1177/0149206307302551

Giuliani, E., \& Macchi, C. (2014). Multinational corporations' economic and human rights impacts on developing countries: a review and research agenda. Cambridge Journal of Economics, 38(2), 479-517. https://doi.org/10.1093/cje/bet060

Giuliani, E., Santangelo, G. D., \& Wettstein, F. (2016). Human rights and international business research: A call for studying emerging market multinationals. Management and Organization Review, 12(3), 631-637. https://doi.org/10.1017/mor.2016.27

Gubbi, S. R., Aulakh, P. S., Ray, S., Sarkar, M. B., \& Chittoor, R. (2010). Do international acquisitions by emerging-economy firms create shareholder value? The case of Indian firms. Journal of International Business Studies, 41(3), 397-418. https://doi.org/10.1057/jibs.2009.47

Guillén, M. F., \& Capron, L. (2016). State capacity, minority shareholder protections, and stock market development. Administrative Science Quarterly, 61(1), 125-160. https://doi.org/10.1177/0001839215601459

Habib, M., \& Zurawicki, L. (2002). Corruption and foreign direct investment. Journal of International Business Studies, 33(2), 291-307. https://doi.org/10.1057/palgrave.jibs.8491017

Hair, J. F., Anderson, R. E., Tatham, R. L., \& Black, W. C. (1998). Multivariate data analysis (5th ed.). Upper Saddle River: Prentice-Hall.

Han, X., Liu, X., Gao, L., \& Ghauri, P. (2018). Chinese multinational enterprises in Europe and Africa: How do they perceive political risk? Management International Review. https://doi.org/10.1007/s11575-017-0331-1

Hernandez, E., \& Guillén, M. F. (2018). What's theoretically novel about emerging-market multinationals? Journal of International Business Studies, 49(1), 24-33. https://doi.org/10.1057/s41267-017-0131-7

Hsieh, N. (2015). Should business have human rights obligations? Journal of Human Rights, 14(2), 218-236. https://doi.org/10.1080/14754835.2015.1007223 
Jackson, G., \& Deeg, R. (2008). Comparing capitalisms: understanding institutional diversity and its implications for international business. Journal of International Business Studies, 39(4), 540561. https://doi.org/10.1057/palgrave.jibs. 8400375

Jensen, N. (2008). Political Risk, Democratic institutions, and foreign direct investment. The Journal of Politics, 70(4), 1040-1052. https://doi.org/10.1017/S0022381608081048

Jormanainen, I., \& Koveshnikov, A. (2012). International activities of emerging market firms. Management International Review, 52(5), 691-725. https://doi.org/10.1007/s11575-011-0115-y

Karhunen, P., \& Ledyaeva, S. (2012). Corruption distance, anti-corruption laws and international ownership strategies in Russia. Journal of International Management, 18(2), 196-208. https://doi.org/10.1016/j.intman.2011.10.002

Kaynak, E., Demirbag, M., \& Tatoglu, E. (2007). Determinants of ownership-based entry mode choice of MNEs: Evidence from Mongolia. Management International Review, 47(4), 505-530. https://doi.org/10.1007/s11575-007-0028-y

Kedia, B., Gaffney, N., \& Clampit, J. (2012). EMNEs and knowledge-seeking FDI. Management International Review, 52(2), 155-173. https://doi.org/10.1007/s11575-012-0132-5

Kedia, B. L., \& Bilgili, T. V. (2015). When history matters: The effect of historical ties on the relationship between institutional distance and shares acquired. International Business Review, 24(6), 921-934. https://doi.org/10.1016/j.ibusrev.2015.01.001

Khan, Z., Wood, G., Tarba, S. Y., Rao-Nicholson, R., \& He, S. (2018). Human resource management in Chinese multinationals in the United Kingdom: The interplay of institutions, culture, and strategic choice. Human Resource Management. https://doi.org/10.1002/hrm.21935

Khanna, T., \& Palepu, K. (1997). Why focused strategies may be wrong for emerging markets. Harvard Business Review, 75(4), 41-48.

King, D. R., Dalton, D. R., Daily, C. M., \& Covin, J. G. (2004). Meta-analyses of post-acquisition performance: indications of unidentified moderators. Strategic Management Journal, 25(2), 187-200. https://doi.org/10.1002/smj.371

Kobrin, S. J. (1979). Political Risk: A Review and Reconsideration. Journal of International Business Studies, 10(1), 67-80. https://doi.org/10.1057/palgrave.jibs.8490631

Kogut, B., \& Chang, S. J. (1991). Technological capabilities and Japanese foreign direct investment in the United States. The Review of Economics and Statistics, 73(3), 401. https://doi.org/10.2307/2109564

Kogut, B., \& Singh, H. (1988). The effect of national culture on the choice of entry mode. Journal of International Business Studies, 19(3), 411-432. https://doi.org/10.1057/palgrave.jibs.8490394

Kolk, A. (2005). Corporate social responsibility in the coffee sector: European Management Journal, 23(2), 228-236. https://doi.org/10.1016/j.emj.2005.02.003

Kolk, A. (2016). The social responsibility of international business: From ethics and the environment to CSR and sustainable development. Journal of World Business, 51(1), 23-34. https://doi.org/10.1016/j.jwb.2015.08.010

Kolk, A., \& Lenfant, F. (2010). MNC Reporting on CSR and conflict in Central Africa. Journal of Business Ethics, 93(S2), 241-255. https://doi.org/10.1007/s10551-009-0271-1

Erramilli, M., Agarwal, S., \& Dev, C. S. (2002). Choice between non-equity entry modes: An organizational capability perspective. Journal of International Business Studies, 33(2), 223-242. https://doi.org/10.1057/palgrave.jibs. 8491014

Lahiri, S., Elango, B., \& Kundu, S. K. (2014). Cross-border acquisition in services: Comparing 
ownership choice of developed and emerging economy MNEs in India. Journal of World Business, 49(3), 409-420. https://doi.org/10.1016/j.jwb.2013.08.003

Li, X., Quan, R., Stoian, M.-C., \& Azar, G. (2018). Do MNEs from developed and emerging economies differ in their location choice of FDI? A 36-year review. International Business Review, 27(5), 1089-1103. https://doi.org/10.1016/j.ibusrev.2018.03.012

Liedong, T. A., \& Frynas, J. G. (2018). Investment climate constraints as determinants of political tie intensity in emerging countries: Evidence from foreign firms in Ghana. Management International Review, 58(5), 675-703. https://doi.org/10.1007/s11575-018-0354-2

Liou, R.-S., Chao, M. C.-H., \& Yang, M. (2016). Emerging economies and institutional quality: Assessing the differential effects of institutional distances on ownership strategy. Journal of World Business, 51(4), 600-611. https://doi.org/10.1016/j.jwb.2016.03.001

Liou, R.-S., Chao, M. C., \& Ellstrand, A. (2017). Unpacking institutional distance: Addressing human capital development and emerging-market firms' ownership strategy in an advanced economy. Thunderbird International Business Review, 59(3), 281-295. https://doi.org/10.1002/tie.21839

Liou, R.-S., \& Rao-Nicholson, R. (2017). Out of Africa: The role of institutional distance and hosthome colonial tie in South African Firms' post-acquisition performance in developed economies. International Business Review, 26(6), 1184-1195. https://doi.org/10.1016/j.ibusrev.2017.04.010

Liou, R.-S., Rao-Nicholson, R., \& Sarpong, D. (2018). What is in a name? Cross-national distances and subsidiary's corporate visual identity change in emerging-market firms' cross-border acquisitions. International Marketing Review, 35(2), 301-319. https://doi.org/10.1108/IMR-102015-0225

Liou, R. S., \& Rao-Nicholson, R. (2019). Age matters: The contingency of economic distance and economic freedom in emerging market firm's cross-border M\&A performance. Management International Review. https://doi.org/10.1007/s11575-019-00381-y

Luo, Y., \& Tung, R. L. (2007). International expansion of emerging market enterprises: A springboard perspective. Journal of International Business Studies, 38(4), 481-498. https://doi.org/10.1057/palgrave.jibs.8400275

Luo, Y., Zhang, H., \& Bu, J. (2019). Developed country MNEs investing in developing economies: Progress and prospect. Journal of International Business Studies, 50(4), 633-667. https://doi.org/10.1057/s41267-019-00230-y

Madhok, A., \& Keyhani, M. (2012). Acquisitions as entrepreneurship: asymmetries, opportunities, and the internationalization of multinationals from emerging economies. Global Strategy Journal, 2(1), 26-40. https://doi.org/10.1002/gsj.1023

Maggioni, D., Santangelo, G. D., \& Koymen-Ozer, S. (2019). MNEs' location strategies and labor standards: The role of operating and reputational considerations across industries. Journal of International Business Studies, 50(6), 948-972. https://doi.org/10.1057/s41267-019-00231-x

Maitland, E., \& Sammartino, A. (2015). Decision making and uncertainty: The role of heuristics and experience in assessing a politically hazardous environment. Strategic Management Journal, 36(10), 1554-1578. https://doi.org/10.1002/smj.2297

Malhotra, S., Lin, X., \& Farrell, C. (2016). Cross-national uncertainty and level of control in crossborder acquisitions: A comparison of Latin American and U.S. multinationals. Journal of Business Research, 69(6), 1993-2004. https://doi.org/10.1016/j.jbusres.2015.10.145

Malhotra, S., Zhu, P., \& Locander, W. (2010). Impact of host-country corruption on U.S. and Chinese cross-border acquisitions. Thunderbird International Business Review, 52(6), 491-507.

https://doi.org/10.1002/tie.20375 
Marano, V., Tashman, P., \& Kostova, T. (2017). Escaping the iron cage: Liabilities of origin and CSR reporting of emerging market multinational enterprises. Journal of International Business Studies, 48(3), 386-408. https://doi.org/10.1057/jibs.2016.17

Meyer, K. E., \& Thein, H. H. (2014). Business under adverse home country institutions: The case of international sanctions against Myanmar. Journal of World Business, 49(1), 156-171. https://doi.org/10.1016/j.jwb.2013.04.005

Meznar, M. B., Nigh, D., \& Kwok, C. C. Y. (1994). Effect of announcements of withdrawal from South Africa on stockholder wealth. Academy of Management Journal, 37(6), 1633-1648. https://doi.org/10.5465/256803

Moeller, S., \& Schlingemann, F. (2005). Global diversification and bidder gains: A comparison between cross-border and domestic acquisitions. Journal of Banking \& Finance, 29(3), 533564. https://doi.org/10.1016/S0378-4266(04)00047-0

Morck, R., Yeung, B., \& Zhao, M. (2008). Perspectives on China's outward foreign direct investment. Journal of International Business Studies, 39(3), 337-350. https://doi.org/10.1057/palgrave.jibs. 8400366

Nicholson, R. R., \& Salaber, J. (2013). The motives and performance of cross-border acquirers from emerging economies: Comparison between Chinese and Indian firms. International Business Review, 22(6), 963-980. https://doi.org/10.1016/j.ibusrev.2013.02.003

North, D. C. (1990). Institutions, Institutional Change and Economic Performance. Institutions, Institutional Change and Economic Performance. Cambridge: Cambridge University Press. https://doi.org/10.1017/CBO9780511808678

Obara, L. J., \& Peattie, K. (2018). Bridging the great divide? Making sense of the human rights-CSR relationship in UK multinational companies. Journal of World Business, 53(6), 781-793. https://doi.org/10.1016/j.jwb.2017.10.002

Orentlicher, D. F., \& Gelatt, T. A. (1993). Public law, private actors: The impact of human rights on business investors in China. Northwestern Journal of International Law \& Business, 14(1), 66129.

Petrou, A. P., \& Thanos, I. C. (2014). The "grabbing hand" or the "helping hand" view of corruption: Evidence from bank foreign market entries. Journal of World Business, 49(3), 444-454. https://doi.org/10.1016/j.jwb.2013.10.004

Puck, J., Lawton, T., \& Mohr, A. (2018). The corporate political activity of MNCs: Taking stock and moving forward. Management International Review, 58(5), 663-673. https://doi.org/10.1007/s11575-018-0364-0

Quer, D., Claver, E., \& Rienda, L. (2012). Political risk, cultural distance, and outward foreign direct investment: Empirical evidence from large Chinese firms. Asia Pacific Journal of Management, 29(4), 1089-1104. https://doi.org/10.1007/s10490-011-9247-7

Rabellotti, R. (2014). What is so special about emerging economy multinational enterprises? Istituto Lombardo-Accademia Di Scienze e Lettere-Rendiconti Di Lettere, 148, 77-95.

Ramamurti, R. (2012). What is really different about emerging market multinationals? Global Strategy Journal, 2(1), 41-47. https://doi.org/10.1002/gsj.1025

Rathert, N. (2016). Strategies of legitimation: MNEs and the adoption of CSR in response to hostcountry institutions. Journal of International Business Studies, 47(7), 858-879. https://doi.org/10.1057/jibs.2016.19

Richards, D. L., Gelleny, R. D., \& Sacko, D. H. (2001). Money with a mean streak? Foreign economic penetration and government respect for human rights in developing countries. 
International Studies Quarterly, 45(2), 219-239. https://doi.org/10.1111/0020-8833.00189

Scherer, A. G., \& Palazzo, G. (2011). The new political role of business in a globalized world: A review of a new perspective on CSR and its implications for the firm, governance, and democracy. Journal of Management Studies, 48(4), 899-931. https://doi.org/10.1111/j.14676486.2010.00950.x

Sen, G. (2007). Informal institutions and gender equality. In J. Jütting, D. Drechsler, S. Bartsch, \& I. de Soysa (Eds.), Informal institutions: How social norms help or hinder development (pp. 4972). Paris: OECD. https://doi.org/10.1787/939b7bcd-en

Shleifer, A., \& Vishny, R. W. (2003). Stock market driven acquisitions. Journal of Financial Economics, 70(3), 295-311. https://doi.org/10.1016/S0304-405X(03)00211-3

Simons, P., \& Macklin, A. (2014). The governance gap: extractive industries, human rights, and the home state advantage. Oxon and New York: Routledge.

Slangen, A. H. L., \& van Tulder, R. J. M. (2009). Cultural distance, political risk, or governance quality? Towards a more accurate conceptualization and measurement of external uncertainty in foreign entry mode research. International Business Review, 18(3), 276-291.

https://doi.org/10.1016/j.ibusrev.2009.02.014

Spar, D. L. (1998). The spotlight and the bottom line: How multinationals export human rights. Foreign Affairs, 77(2), 7. https://doi.org/10.2307/20048784

Sullivan, R. (2017). Business and Human Rights: Dilemmas and Solutions. Routledge. https://doi.org/10.4324/9781351281287

Tekin-Koru, A. (2006). Corruption and the ownership composition of the multinational firm at the time of entry: Evidence from Turkey. Journal of Economics and Finance, 30(2), 251-269. https://doi.org/10.1007/BF02761490

Uhlenbruck, K., Rodriguez, P., Doh, J., \& Eden, L. (2006). The impact of corruption on entry strategy: Evidence from telecommunication projects in emerging economies. Organization Science, 17(3), 402-414. https://doi.org/10.1287/orsc.1060.0186

United Nations Conference on Trade and Development. (2014). World Investment Report 2014: Investing in SDGs: An Action Plan. World Investment Report. https://doi.org/978-92-1-112873-4

Vadlamannati, K. C., Janz, N., \& Berntsen, Ø. I. (2018). Human rights shaming and FDI: Effects of the UN Human Rights Commission and Council. World Development, 104, 222-237. https://doi.org/10.1016/j.worlddev.2017.11.014

Vogel, D. J. (2005). Is there a market for virtue? The business case for corporate social responsibility. California Management Review, 47(4), 19-45. https://doi.org/10.2307/41166315

Voinea, C. L., \& van Kranenburg, H. (2018). Feeling the squeeze: Nonmarket institutional pressures and firm nonmarket strategies. Management International Review, 58(5), 705-741. https://doi.org/10.1007/s11575-018-0355-1

Walsh, J. I., \& Piazza, J. A. (2010). Why respecting physical integrity rights reduces terrorism. Comparative Political Studies, 43(5), 551-577. https://doi.org/10.1177/0010414009356176

Wei, S.-J. (2000). How taxing is corruption on international investors? Review of Economics and Statistics, 82(1), 1-11. https://doi.org/10.1162/003465300558533

Wei, S. (1997). Why is Corruption So Much More Taxing Than Tax? Arbitrariness Kills. NBER Working Paper. Cambridge, MA. https://doi.org/10.3386/w6255

Wettstein, F. (2010). The duty to protect: Corporate complicity, political responsibility, and human rights advocacy. Journal of Business Ethics. https://doi.org/10.1007/s10551-010-0447-8 
Wettstein, F. (2012). CSR and the debate on business and human rights: Bridging the great divide. Business Ethics Quarterly, 22(4), 739-770. https://doi.org/10.5840/beq201222446

Wettstein, F., Giuliani, E., Santangelo, G. D., \& Stahl, G. K. (2019). International business and human rights: A research agenda. Journal of World Business, 54(1), 54-65. https://doi.org/10.1016/j.jwb.2018.10.004

Xie, E., Reddy, K. S., \& Liang, J. (2017). Country-specific determinants of cross-border mergers and acquisitions: A comprehensive review and future research directions. Journal of World Business, 52(2), 127-183. https://doi.org/10.1016/j.jwb.2016.12.005

Zheng, N., Wei, Y., Zhang, Y., \& Yang, J. (2016). In search of strategic assets through cross-border merger and acquisitions: Evidence from Chinese multinational enterprises in developed economies. International Business Review, 25(1), 177-186.

https://doi.org/10.1016/j.ibusrev.2014.11.009

Zhu, J. S., Zhu, C. J., \& De Cieri, H. (2014). Chinese MNCs' preparation for host-country labor relations: An exploration of country-of-origin effect. Human Resource Management, 53(6), 947-965. https://doi.org/10.1002/hrm.21613 
Table 1. Key characteristics of the acquisitions

\begin{tabular}{|c|c|c|c|}
\hline $\begin{array}{l}\text { Acquirers' home } \\
\text { country }\end{array}$ & $\begin{array}{l}\text { Number of } \\
\text { deals }\end{array}$ & $\begin{array}{l}\% \text { of } \\
\text { deals }\end{array}$ & $\begin{array}{l}\text { Average } \\
\text { Deal value (\$Mil) }\end{array}$ \\
\hline Malaysia & 264 & $9 \%$ & 65.58 \\
\hline India & 237 & $8 \%$ & 93.9 \\
\hline China & 199 & $7 \%$ & 203.79 \\
\hline South Africa & 160 & $6 \%$ & 146.07 \\
\hline Russia & 104 & $4 \%$ & 332.27 \\
\hline United Arab Emirates & 80 & $3 \%$ & 751.89 \\
\hline Brazil & 64 & $2 \%$ & 571.71 \\
\hline Mexico & 51 & $2 \%$ & 491.66 \\
\hline Thailand & 64 & $2 \%$ & 74.24 \\
\hline Chile & 49 & $2 \%$ & 80.59 \\
\hline Poland & 54 & $2 \%$ & 42.13 \\
\hline Argentina & 35 & $1 \%$ & 120.29 \\
\hline Turkey & 19 & $1 \%$ & 82.82 \\
\hline Indonesia & 21 & $1 \%$ & 125.12 \\
\hline United States & 1401 & $50 \%$ & 75.28 \\
\hline Grand Total & 2802 & $100 \%$ & \\
\hline \multicolumn{4}{|l|}{ Acquirers' industry } \\
\hline Manufacturing & 1278 & $46 \%$ & \\
\hline Financials & 496 & $18 \%$ & \\
\hline Materials & 220 & $8 \%$ & \\
\hline Energy and Power & 110 & $4 \%$ & \\
\hline Services & 148 & $5 \%$ & \\
\hline Staples & 304 & $11 \%$ & \\
\hline Others & 180 & $6 \%$ & \\
\hline Construction & 66 & $2 \%$ & \\
\hline \multicolumn{4}{|l|}{ Target Country } \\
\hline United Kingdom & 296 & $11 \%$ & \\
\hline Australia & 286 & $10 \%$ & \\
\hline Canada & 140 & $5 \%$ & \\
\hline Brazil & 92 & $3 \%$ & \\
\hline China & 86 & $3 \%$ & \\
\hline Argentina & 84 & $3 \%$ & \\
\hline Singapore & 76 & $3 \%$ & \\
\hline Hong Kong & 72 & $3 \%$ & \\
\hline Germany & 68 & $2 \%$ & \\
\hline India & 64 & $2 \%$ & \\
\hline \multicolumn{4}{|l|}{ Target market status } \\
\hline Developed & 1616 & $58 \%$ & \\
\hline Emerging & 1186 & $42 \%$ & \\
\hline
\end{tabular}


Table 2. Variables, measures and data sources

\begin{tabular}{|c|c|c|c|}
\hline & Variable name & Description/Measure & Source \\
\hline $\begin{array}{l}\text { Dependent } \\
\text { variable }\end{array}$ & Ownership Level & Acquirer stakes in the target after the transaction. & SDC Platinum database \\
\hline $\begin{array}{l}\text { Independent } \\
\text { variable }\end{array}$ & $\begin{array}{l}\text { Physical integrity rights } \\
\text { index, Empowerment rights } \\
\text { index }\end{array}$ & $\begin{array}{l}\text { All indicators take values between } 0 \text { (frequent occurrences), } 1 \text { (occasional occurrences), and } 2 \text { (no occurrences). } \\
\text { The composite host country human rights values range from } 0 \text { to } 22 \text {. Physical integrity rights index ranges } \\
\text { between } 0 \text { and } 8 \text {, and Empowerment rights index range between } 0 \text { and } 14 \text {. }\end{array}$ & $\begin{array}{l}\text { Cingranelli \& Richards } \\
\text { (1999), Cingranelli, Richards } \\
\text { \& Clay (2014) }\end{array}$ \\
\hline \multirow[t]{12}{*}{$\begin{array}{l}\text { Control } \\
\text { variables }\end{array}$} & $\begin{array}{l}\text { Formal institutional } \\
\text { distance }\end{array}$ & $\begin{array}{l}\text { Ten economic freedom elements of each market are used to obtain the score difference between the acquiring } \\
\text { firm's home and target country. }\end{array}$ & Heritage Foundation \\
\hline & Cultural distances & $\begin{array}{l}\text { The cultural distance between the acquirer and target countries is calculated by using the power distance, } \\
\text { uncertainty avoidance, individualism, masculinity, long term orientation, and indulgence. }\end{array}$ & Hofstede website (2016) \\
\hline & Same industry & $\begin{array}{l}\text { Measured using the four-digit SIC codes of the acquirer and target firms, and coded } 1 \text { when both firms have the } \\
\text { same codes and } 0 \text { if otherwise. }\end{array}$ & \multirow[t]{6}{*}{ SDC Platinum database } \\
\hline & Deal value & Log of the deal value & \\
\hline & Cash & Coded as 1 if the transaction is in cash and 0 if otherwise. & \\
\hline & Government Ownership & If acquirer majority-owned by a government agency, this is coded as 1 and 0 if otherwise. & \\
\hline & Past experience & For acquirers with past cross-border experience, this is coded as 1 and 0 otherwise. & \\
\hline & Public target & For the publicly-listed target, this variable is coded as 1 and 0 otherwise. & \\
\hline & GDP distance & The difference in the GDP per capita of the home and host countries. & The World Bank \\
\hline & $\begin{array}{l}\text { Minority shareholder } \\
\text { protection (HOST) }\end{array}$ & Protection of the minority shareholders in the acquirer's host country. & Guillén \& Capron (2015) \\
\hline & $\begin{array}{l}\text { Inward foreign direct } \\
\text { investment }\end{array}$ & Inward foreign direct investment in the target country. & \multirow[t]{2}{*}{ The World Bank } \\
\hline & Home country GDP & Acquirer's home country GDP per capita. & \\
\hline
\end{tabular}


Table 3. Descriptive Statistics

\begin{tabular}{|c|c|c|c|c|c|c|c|c|c|c|c|c|c|c|c|}
\hline $\begin{array}{l}\text { Sr. } \\
\text { No. } \\
\end{array}$ & Variable & Mean & $\begin{array}{l}\text { Std. } \\
\text { Dev. }\end{array}$ & 1 & 2 & 3 & 4 & 5 & 6 & 7 & 8 & 9 & 10 & 11 & 12 \\
\hline \multirow[t]{2}{*}{1} & Ownership Level & 72.57 & 32.37 & 1.000 & & & & & & & & & & & \\
\hline & Phycical intearity rights ind & 516 & 256 & 0092 & 1000 & & & & & & & & & & \\
\hline 2 & & & & $* * *$ & & & & & & & & & & & \\
\hline \multirow[t]{2}{*}{3} & Empowerment rights index & 9.88 & 4.25 & 0.067 & 0.705 & 1.000 & & & & & & & & & \\
\hline & & & & $* * *$ & $* * *$ & & & & & & & & & & \\
\hline \multirow[t]{2}{*}{4} & Formal institutional distance & 13.11 & 9.66 & -0.020 & -0.178 & -0.209 & 1.000 & & & & & & & & \\
\hline & & & & & $* * *$ & $* * *$ & & & & & & & & & \\
\hline \multirow[t]{2}{*}{5} & Cultural distance & 64.24 & 31.18 & -0.024 & -0.204 & -0.310 & 0.604 & 1.000 & & & & & & & \\
\hline & & & & & **** & **** & *** & & & & & & & & \\
\hline \multirow[t]{2}{*}{6} & Same industry & 0.46 & 0.49 & 0.085 & -0.026 & 0.036 & 0.006 & -0.030 & 1.000 & & & & & & \\
\hline & & & & $* * *$ & & $* *$ & & & & & & & & & \\
\hline \multirow[t]{2}{*}{7} & Deal value & 138.80 & 608.08 & 0.046 & 0.039 & 0.064 & 0.029 & 0.046 & 0.021 & 1.000 & & & & & \\
\hline & & & & *** & ** & $* * *$ & & ** & & & & & & & \\
\hline \multirow[t]{2}{*}{8} & Cash & 0.42 & 0.49 & -0.009 & -0.034 & 0.006 & 0.061 & 0.037 & 0.004 & 0.016 & 1.000 & & & & \\
\hline & & & & & * & & $* * *$ & * & & & & & & & \\
\hline \multirow[t]{2}{*}{9} & Past experience & 0.44 & 0.49 & 0.007 & 0.001 & 0.039 & -0.041 & -0.047 & 0.014 & 0.083 & 0.032 & 1.000 & & & \\
\hline & & & & & & ** & * & ** & & $* * *$ & * & & & & \\
\hline \multirow[t]{2}{*}{10} & GDP distance & 0.75 & 0.45 & 0.035 & 0.174 & 0.103 & 0.343 & 0.162 & 0.007 & 0.084 & -0.052 & -0.105 & 1.000 & & \\
\hline & & & & * & $* * *$ & $* * *$ & $* * *$ & **** & & *** & $* * *$ & $* * *$ & & & \\
\hline \multirow[t]{2}{*}{11} & Minority shareholder protection (HOST) & 6.23 & 1.02 & -0.045 & 0.113 & -0.093 & 0.044 & -0.041 & -0.011 & 0.018 & -0.002 & -0.038 & 0.077 & 1.000 & \\
\hline & & & & ** & $* * *$ & $* * *$ & ** & ** & & & & * & $* * *$ & & \\
\hline \multirow[t]{2}{*}{12} & Inward foreign direct investment & 40711.4 & 45630.6 & 0.110 & 0.088 & 0.074 & -0.014 & -0.064 & 0.007 & 0.068 & -0.007 & -0.047 & 0.052 & 0.257 & 1.000 \\
\hline & & & & **** & **** & $* * *$ & & **** & & *** & & ** & **** & $* * *$ & \\
\hline
\end{tabular}

${ }_{* * *} \mathrm{p}<0.01,{ }^{* *} \mathrm{p}<0.05,{ }^{*} \mathrm{p}<0.1$ 
Table 4. Results of the Regression Analysis for the Degree of Ownership in Cross-border acquisitions (columns 1-3) \& Results of the Analysis using composite indices (columns 4-5) \& two different classification of Ownership: one, Majority Ownership (0/1) analyzed using the Probit model, and two, Ordered Ownership Level (3/2/1) analyzed using the Ordered Probit model (columns 6-9)

\begin{tabular}{|c|c|c|c|c|c|c|c|c|c|}
\hline VARIABLES & $(1)$ & $(2)$ & (3) & (4) & (5) & $(6)$ & $(7)$ & $(8)$ & (9) \\
\hline \multirow[t]{2}{*}{$\begin{array}{l}\text { Physical integrity rights } \\
\text { index }\end{array}$} & & $0.678^{*}$ & & & & $0.029 *$ & & 0.017 & \\
\hline & & $(0.354)$ & & & & $(0.015)$ & & $(0.013)$ & \\
\hline \multirow[t]{2}{*}{$\begin{array}{l}\text { Empowerment rights } \\
\text { index }\end{array}$} & & & 0.207 & & & & 0.009 & & 0.010 \\
\hline & & & $(0.191)$ & & & & $(0.008)$ & & $(0.007)$ \\
\hline \multirow[t]{2}{*}{ Host Human Rights } & & & & 0.210 & & & & & \\
\hline & & & & $(0.140)$ & & & & & \\
\hline \multirow[t]{2}{*}{$\begin{array}{l}\text { Host Human Rights } \\
\text { (PCA) }\end{array}$} & & & & & $1.136^{*}$ & & & & \\
\hline & & & & & $(0.686)$ & & & & \\
\hline \multirow[t]{2}{*}{$\begin{array}{l}\text { Formal institutional } \\
\text { distance }\end{array}$} & $-0.162^{*}$ & -0.114 & $-0.147^{*}$ & -0.131 & -0.126 & $\begin{array}{l}- \\
0.0010 \\
4\end{array}$ & $\begin{array}{l}- \\
0.0023 \\
8 \\
\end{array}$ & $\begin{array}{l}- \\
0.0037 \\
3\end{array}$ & \begin{tabular}{|l|}
- \\
0.0041 \\
5 \\
\end{tabular} \\
\hline & $(0.086)$ & $(0.090)$ & $(0.088)$ & $(0.089)$ & $(0.089)$ & $(0.004)$ & $(0.004)$ & $(0.003)$ & $(0.003)$ \\
\hline \multirow[t]{2}{*}{ Cultural distance } & 0.024 & 0.034 & 0.033 & 0.036 & 0.037 & 0.000 & 0.000 & -0.000 & -0.000 \\
\hline & $(0.027)$ & $(0.028)$ & $(0.028)$ & $(0.028)$ & $(0.028)$ & $(0.001)$ & $(0.001)$ & $(0.001)$ & $(0.001)$ \\
\hline \multirow[t]{2}{*}{ Same industry } & $\begin{array}{l}2.673 * \\
*\end{array}$ & $\begin{array}{l}2.725^{*} \\
*\end{array}$ & $\begin{array}{l}2.656^{*} \\
*\end{array}$ & $\begin{array}{l}2.672^{*} \\
*\end{array}$ & $\begin{array}{l}2.682 * \\
*\end{array}$ & 0.084 & 0.081 & 0.064 & 0.062 \\
\hline & $(1.344)$ & $(1.346)$ & $(1.344)$ & $(1.344)$ & $(1.344)$ & $(0.062)$ & $(0.062)$ & $(0.051)$ & $(0.051)$ \\
\hline \multirow[t]{2}{*}{ Deal value } & $\begin{array}{l}0.003 * \\
* *\end{array}$ & $\begin{array}{l}0.003 * \\
* *\end{array}$ & $\begin{array}{l}0.003 * \\
* *\end{array}$ & $\begin{array}{l}0.003 * \\
* *\end{array}$ & $\begin{array}{l}0.003 * \\
* *\end{array}$ & $\begin{array}{l}0.000 * \\
* *\end{array}$ & $\begin{array}{l}0.000^{*} \\
* *\end{array}$ & $\begin{array}{l}0.000 * \\
* *\end{array}$ & $\begin{array}{l}0.000 * \\
* *\end{array}$ \\
\hline & $(0.000)$ & $(0.000)$ & $(0.000)$ & $(0.000)$ & $(0.000)$ & $(0.004)$ & $(0.005)$ & $(0.000)$ & $(0.000)$ \\
\hline \multirow{2}{*}{ Cash } & 0.522 & 0.509 & 0.440 & 0.435 & 0.442 & -0.020 & -0.022 & 0.009 & 0.006 \\
\hline & $(1.269)$ & $(1.267)$ & $(1.269)$ & $(1.268)$ & $(1.268)$ & $(0.057)$ & $(0.057)$ & $(0.047)$ & $(0.047)$ \\
\hline \multirow[t]{2}{*}{ Past experience } & 1.037 & 0.971 & 0.974 & 0.953 & 0.950 & 0.020 & 0.019 & 0.039 & 0.038 \\
\hline & $(1.274)$ & $(1.274)$ & $(1.277)$ & $(1.277)$ & $(1.276)$ & $(0.058)$ & $(0.058)$ & $(0.048)$ & $(0.048)$ \\
\hline \multirow[t]{2}{*}{ GDP distance } & $\begin{array}{l}24.06^{*} \\
* *\end{array}$ & 12.81 & $\begin{array}{l}20.04 * \\
* *\end{array}$ & $\begin{array}{l}16.50^{*} \\
*\end{array}$ & $15.26^{*}$ & 0.491 & $\begin{array}{l}0.800 * \\
*\end{array}$ & $\begin{array}{l}1.040^{*} \\
* *\end{array}$ & $\begin{array}{l}1.125^{*} \\
* * \\
\end{array}$ \\
\hline & $(6.569)$ & $(8.607)$ & $(7.337)$ & $(8.015)$ & $(8.238)$ & $(0.394)$ & $(0.337)$ & $(0.323)$ & $(0.274)$ \\
\hline \multirow[t]{2}{*}{$\begin{array}{l}\text { Minority shareholder } \\
\text { protection (HOST) }\end{array}$} & $\begin{array}{l}- \\
1.970 * \\
* *\end{array}$ & $\begin{array}{l}- \\
1.835^{*} \\
* *\end{array}$ & $\begin{array}{l}- \\
1.744 * \\
* *\end{array}$ & $\begin{array}{l}- \\
1.699 * \\
* *\end{array}$ & $\begin{array}{l}- \\
1.703 * \\
* *\end{array}$ & $\begin{array}{l}- \\
0.110^{*} \\
* *\end{array}$ & $\begin{array}{l}- \\
0.103 * \\
* *\end{array}$ & $\begin{array}{l}- \\
0.0761 \\
* * *\end{array}$ & $\begin{array}{l}- \\
0.0672 \\
* *\end{array}$ \\
\hline & $(0.636)$ & $(0.636)$ & $(0.663)$ & $(0.656)$ & $(0.652)$ & $(0.032)$ & $(0.034)$ & $(0.025)$ & $(0.026)$ \\
\hline \multirow[t]{2}{*}{$\begin{array}{l}\text { Inward foreign direct } \\
\text { investment }\end{array}$} & $\begin{array}{l}0.000^{*} \\
* *\end{array}$ & $\begin{array}{l}0.000^{*} \\
* *\end{array}$ & $\begin{array}{l}0.000^{*} \\
* *\end{array}$ & $\begin{array}{l}0.000^{*} \\
* *\end{array}$ & $\begin{array}{l}0.000^{*} \\
* *\end{array}$ & $\begin{array}{l}0.000^{*} \\
* *\end{array}$ & $\begin{array}{l}0.000^{*} \\
* *\end{array}$ & $\begin{array}{l}0.000^{*} \\
* *\end{array}$ & $\begin{array}{l}0.000^{*} \\
* *\end{array}$ \\
\hline & $(0.001)$ & $(0.000)$ & $(0.001)$ & $(0.000)$ & $(0.000)$ & $(0.001)$ & $(0.002)$ & $(0.000)$ & $(0.000)$ \\
\hline $\begin{array}{l}\text { Year, Industry, Country } \\
\text { dummies }\end{array}$ & $\begin{array}{l}\text { Include } \\
\mathrm{d}\end{array}$ & $\begin{array}{l}\text { Include } \\
\mathrm{d}\end{array}$ & $\begin{array}{l}\text { Include } \\
\text { d }\end{array}$ & $\begin{array}{l}\text { Include } \\
\mathrm{d}\end{array}$ & $\begin{array}{l}\text { Include } \\
\mathrm{d}\end{array}$ & $\begin{array}{l}\text { Include } \\
\mathrm{d}\end{array}$ & $\begin{array}{l}\text { Include } \\
\text { d }\end{array}$ & $\begin{array}{l}\text { Include } \\
\mathrm{d}\end{array}$ & $\begin{array}{l}\text { Include } \\
\mathrm{d}\end{array}$ \\
\hline \multirow[t]{2}{*}{ Constant } & $\begin{array}{l}64.89 * \\
* *\end{array}$ & $\begin{array}{l}66.10^{*} \\
* *\end{array}$ & $\begin{array}{l}60.33 * \\
* *\end{array}$ & $\begin{array}{l}62.16^{*} \\
* *\end{array}$ & $\begin{array}{l}66.48 * \\
* *\end{array}$ & 0.113 & 0.0542 & & \\
\hline & $(12.38)$ & $(12.10)$ & $(11.86)$ & $(11.89)$ & $(12.34)$ & $(0.424)$ & $(0.446)$ & & \\
\hline \multirow[t]{2}{*}{ Constant cut 1} & & & & & & & & -0.237 & -0.135 \\
\hline & & & & & & & & $(0.454)$ & $(0.467)$ \\
\hline \multirow[t]{2}{*}{ Constant cut 2} & & & & & & & & 0.507 & 0.609 \\
\hline & & & & & & & & $(0.000)$ & $(0.000)$ \\
\hline Observations & 2,538 & 2,538 & 2,538 & 2,538 & 2,538 & 2,538 & 2,538 & 2,538 & 2,538 \\
\hline Pseudo R-squared & 0.220 & 0.220 & 0.220 & 0.0970 & 0.0971 & & & & \\
\hline Log-Likelihood & & & & & & $\begin{array}{l}- \\
1318.3 \\
649 \\
\end{array}$ & $\begin{array}{l}- \\
1319.4 \\
708 \\
\end{array}$ & $\begin{array}{l}- \\
2523.8 \\
233 \\
\end{array}$ & $\begin{array}{l}- \\
2523.6 \\
338 \\
\end{array}$ \\
\hline
\end{tabular}

$\mathrm{p}$-values in parentheses, ${ }^{* * *} \mathrm{p}<0.01,{ }^{*} * \mathrm{p}<0.05,{ }^{*} \mathrm{p}<0.1$ 
Table 5. Two sub-indicators, Financial Freedom distance and Property Rights distance are used to examine the impact of institutional distance and human rights on the ownership

\begin{tabular}{lllll}
\hline VARIABLES & \multicolumn{1}{c}{$(1)$} & \multicolumn{1}{c}{$(2)$} & \multicolumn{1}{c}{$(3)$} & \multicolumn{1}{c}{$(4)$} \\
\hline Physical integrity rights index & $0.874^{* *}$ & & $0.924^{* * *}$ & \\
Empowerment rights index & $(0.341)$ & & $(0.355)$ & \\
& & $0.344^{*}$ & & 0.289 \\
Financial Freedom distance & & $(0.190)$ & & $(0.190)$ \\
& $-0.0817^{*}$ & $-0.0875^{* *}$ & & \\
Property Rights distance & $(0.0427)$ & $(0.0433)$ & & \\
& & & -0.0519 & -0.0319 \\
Cultural distance & & & $(0.0447)$ & $(0.0434)$ \\
& 0.00134 & -0.00447 & 0.0106 & 0.00620 \\
Same industry & $(0.0268)$ & $(0.0269)$ & $(0.0260)$ & $(0.0268)$ \\
& $2.628^{*}$ & $2.514^{*}$ & $2.625^{*}$ & $2.546^{*}$ \\
Deal value & $(1.348)$ & $(1.346)$ & $(1.352)$ & $(1.350)$ \\
& $0.003^{* * *}$ & $0.003^{* * *}$ & $0.003^{* * *}$ & $0.003^{* * *}$ \\
Cash & $(0.000)$ & $(0.000)$ & $(0.000)$ & $(0.000)$ \\
Past experience & 0.313 & 0.146 & 0.351 & 0.217 \\
& $(1.264)$ & $(1.265)$ & $(1.265)$ & $(1.267)$ \\
GDP distance & 0.910 & 0.876 & 0.901 & 0.890 \\
& $(1.273)$ & $(1.276)$ & $(1.273)$ & $(1.277)$ \\
Minority shareholder protection (HOST) & $-1.946^{* * *}$ & $-1.762^{* * *}$ & $-1.804^{* * *}$ & $-1.682^{* *}$ \\
& $(0.644)$ & $(0.668)$ & $(0.635)$ & $(0.662)$ \\
Inward foreign direct investment & $0.000^{* * *}$ & $0.000^{* * *}$ & $0.000^{* * *}$ & $0.000^{* * *}$ \\
& $(0.001)$ & $(0.001)$ & $(0.000)$ & $(0.000)$ \\
Year, Industry, Country dummies & Included & Included & Included & Included \\
Constant & $63.94^{* * *}$ & $56.41^{* * *}$ & $64.06^{* * *}$ & $58.20^{* * *}$ \\
& $(12.21)$ & $(12.10)$ & $(12.36)$ & $(12.40)$ \\
Observations & 2,538 & 2,538 & 2,538 & 2,538 \\
Pseudo R-squared & 0.113 & 0.112 & 0.112 & 0.111 \\
\hline P-Valus in para & & &
\end{tabular}

p-values in parentheses, ${ }^{* * *} \mathrm{p}<0.01,{ }^{* *} \mathrm{p}<0.05,{ }^{*} \mathrm{p}<0.1$ 
Table 6. Matched sample analysis of Developed (DM) and Emerging Market (EM) firms

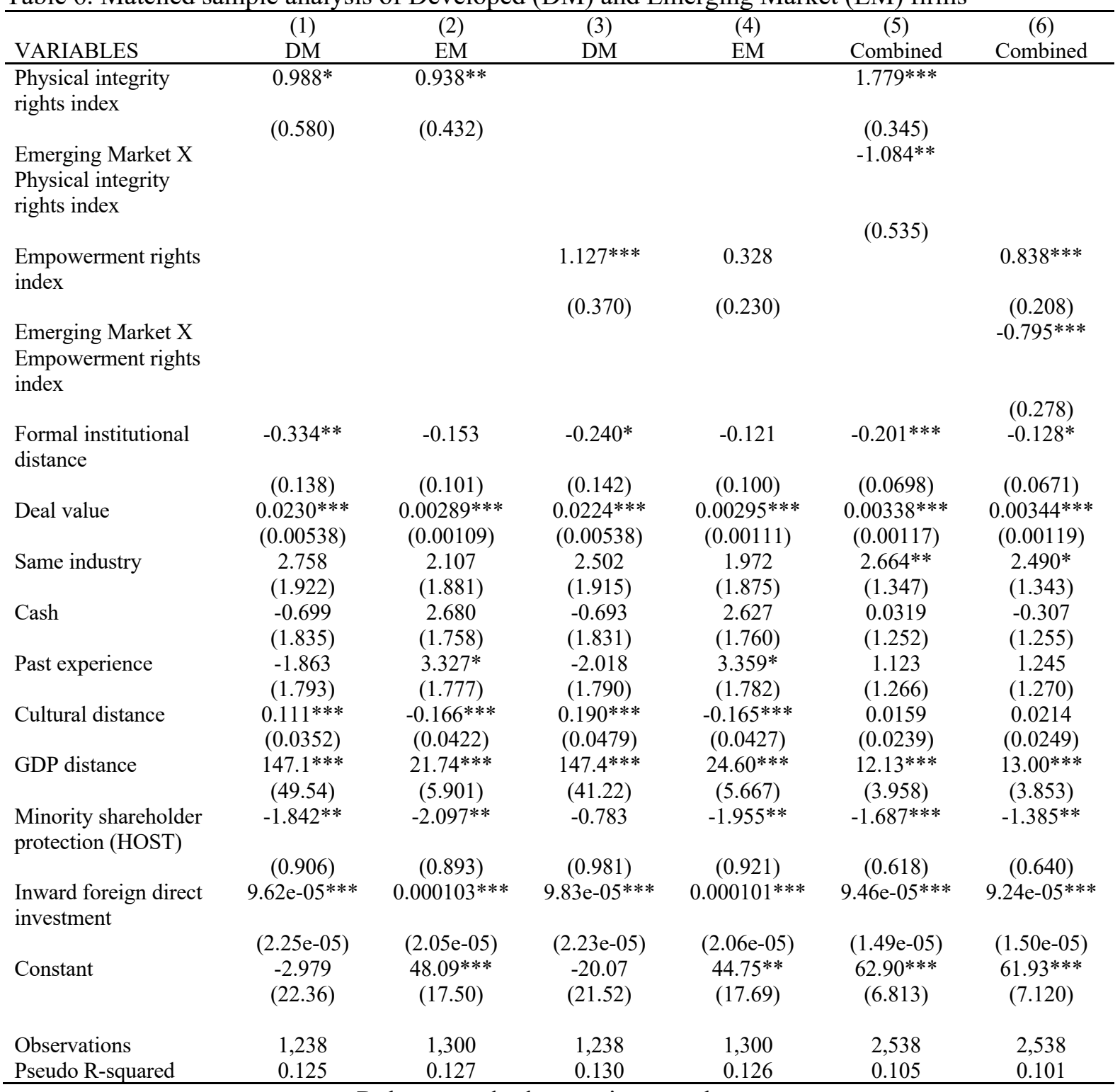

Robust standard errors in parentheses

$* * * \mathrm{p}<0.01, * * \mathrm{p}<0.05, * \mathrm{p}<0.1$ 
Table 7. Results of the Regression Analysis for the Matched sample for the Degree of Ownership in Cross-border acquisitions using composite indices (columns 1-4) \& two different classification of Ownership: one, Majority Ownership (0/1) analyzed using the Probit model (columns 5-8), and two, Ordered Ownership Level (3/2/1) analyzed using the Ordered Probit model (columns 9-12)

\begin{tabular}{|c|c|c|c|c|c|c|c|c|c|c|c|c|}
\hline VARIABLES & $\begin{array}{l}(1) \\
\text { DM } \\
\end{array}$ & $\begin{array}{l}(2) \\
\text { EM } \\
\end{array}$ & $\begin{array}{l}(3) \\
\text { DM } \\
\end{array}$ & $\begin{array}{l}(4) \\
\text { EM } \\
\end{array}$ & $\begin{array}{l}(5) \\
(\mathrm{DM})\end{array}$ & $\begin{array}{l}(6) \\
(\mathrm{EM}) \\
\end{array}$ & $\begin{array}{l}(7) \\
(\mathrm{DM})\end{array}$ & $\begin{array}{l}(8) \\
(\mathrm{EM})\end{array}$ & $\begin{array}{l}(9) \\
(\mathrm{DM})\end{array}$ & $\begin{array}{l}(10) \\
(\mathrm{EM}) \\
\end{array}$ & $\begin{array}{l}(11) \\
(\mathrm{DM})\end{array}$ & $\begin{array}{l}(12) \\
(\mathrm{EM})\end{array}$ \\
\hline Host Human Rights & $\begin{array}{c}0.761^{* * *} \\
(0.265)\end{array}$ & $\begin{array}{l}0.297 * \\
(0.164)\end{array}$ & & & & & & & & & & \\
\hline $\begin{array}{l}\text { Host Human Rights } \\
\text { (PCA) }\end{array}$ & & & $3.462 * * *$ & $1.559^{*}$ & & & & & & & & \\
\hline $\begin{array}{l}\text { Physical integrity } \\
\text { rights index }\end{array}$ & & & $(1.280)$ & $(0.811)$ & $0.0501^{*}$ & $0.0388^{* *}$ & & & 0.0105 & $0.0336 * *$ & & \\
\hline $\begin{array}{l}\text { Empowerment rights } \\
\text { index }\end{array}$ & & & & & $(0.0266)$ & $(0.0191)$ & $0.0568^{* * *}$ & 0.0150 & $(0.0216)$ & $(0.0165)$ & $0.0289^{* *}$ & $0.0178^{* *}$ \\
\hline $\begin{array}{l}\text { Formal institutional } \\
\text { distance }\end{array}$ & $-0.245^{*}$ & -0.132 & $-0.259 *$ & -0.136 & $-0.0109 *$ & -0.00368 & $\begin{array}{r}(0.0187) \\
-0.00657\end{array}$ & $\begin{array}{l}(0.0104) \\
-0.00254\end{array}$ & $-0.0123 * *$ & -0.00283 & $\begin{array}{c}(0.0141) \\
-0.00900^{*}\end{array}$ & $\begin{array}{l}(0.00874) \\
-0.00178\end{array}$ \\
\hline & $(0.143)$ & $(0.100)$ & $(0.143)$ & $(0.100)$ & $(0.00664)$ & $(0.00459)$ & $(0.00681)$ & $(0.00454)$ & $(0.00523)$ & $(0.00379)$ & $(0.00542)$ & $(0.00377)$ \\
\hline Deal value & $\begin{array}{c}0.0226 * * * \\
(0.00536)\end{array}$ & $\begin{array}{c}0.00291 * * * \\
(0.00110)\end{array}$ & $\begin{array}{c}0.0227^{* * *} \\
(0.00536)\end{array}$ & $\begin{array}{c}0.00290^{* * *} \\
(0.00110)\end{array}$ & $\begin{array}{c}0.000817^{* * *} \\
(0.000292)\end{array}$ & $\begin{array}{l}0.000178^{*} \\
(0.000101)\end{array}$ & $\begin{array}{c}0.000787 * * * \\
(0.000291)\end{array}$ & $\begin{array}{l}0.000183^{*} \\
(0.000102)\end{array}$ & $\begin{array}{c}0.000798^{* * *} * \\
(0.000236)\end{array}$ & $\begin{array}{c}0.000104 \\
(6.60 \mathrm{e}-05)\end{array}$ & $\begin{array}{c}0.000788^{* * *} \\
(0.000236)\end{array}$ & $\begin{array}{c}0.000104 \\
(6.64 \mathrm{e}-05)\end{array}$ \\
\hline Same industry & $\begin{array}{c}2.590 \\
(1.919)\end{array}$ & $\begin{array}{l}2.009 \\
(1.875)\end{array}$ & $\begin{array}{c}2.633 \\
(1.920)\end{array}$ & $\begin{array}{c}2.027 \\
(1.876)\end{array}$ & $\begin{array}{l}0.0791 \\
(0.0890)\end{array}$ & $\begin{array}{c}0.0582 \\
(0.0879)\end{array}$ & $\begin{array}{c}0.0692 \\
(0.0890)\end{array}$ & $\begin{array}{c}0.0539 \\
(0.0877)\end{array}$ & $\begin{array}{c}0.0626 \\
(0.0736)\end{array}$ & $\begin{array}{c}0.0442 \\
(0.0728)\end{array}$ & $\begin{array}{c}0.0543 \\
(0.0738)\end{array}$ & $\begin{array}{c}0.0381 \\
(0.0727)\end{array}$ \\
\hline Cash & $\begin{array}{l}-0.691 \\
(1.830)\end{array}$ & $\begin{array}{c}2.641 \\
(1.759)\end{array}$ & $\begin{array}{l}-0.692 \\
(1.830)\end{array}$ & $\begin{array}{c}2.648 \\
(1.759)\end{array}$ & $\begin{array}{r}-0.0559 \\
(0.0822)\end{array}$ & $\begin{array}{c}0.0931 \\
(0.0818)\end{array}$ & $\begin{array}{l}-0.0595 \\
(0.0823)\end{array}$ & $\begin{array}{c}0.0897 \\
(0.0817)\end{array}$ & $\begin{array}{r}-0.00135 \\
(0.0701)\end{array}$ & $\begin{array}{c}0.0637 \\
(0.0674)\end{array}$ & $\begin{array}{r}-0.00279 \\
(0.0701)\end{array}$ & $\begin{array}{c}0.0616 \\
(0.0673)\end{array}$ \\
\hline Cultural distance & $0.176^{* * *}$ & $-0.168 * * *$ & $0.164^{* * *}$ & $-0.168 * * *$ & $0.00517^{* * *}$ & - & $0.00916^{* * *}$ & - & 0.00186 & - & $0.00425^{* *}$ & - \\
\hline & $(0.0452)$ & $(0.0426)$ & $(0.0432)$ & $(0.0426)$ & $(0.00$ & $\begin{array}{c}0.00764 * * * \\
(0.00184)\end{array}$ & $(0.00235)$ & $\begin{array}{c}0.00768 * * * \\
(0.00184)\end{array}$ & $(0.00127)$ & $\begin{array}{c}0.00537 * * * \\
(0.00158)\end{array}$ & $(0.00176)$ & $\begin{array}{c}0.00557^{* * *} \\
(0.00160)\end{array}$ \\
\hline GDP distance & $\begin{array}{c}124.4^{* * *} \\
(45.96)\end{array}$ & $\begin{array}{c}23.18^{* * *} \\
(5.797)\end{array}$ & $\begin{array}{c}122.7 * * * \\
(47.46)\end{array}$ & $\begin{array}{c}22.71^{* * *} \\
(5.837)\end{array}$ & $\begin{array}{l}5.447 * * \\
(2.386)\end{array}$ & $\begin{array}{c}0.806^{* * *} \\
(0.311)\end{array}$ & $\begin{array}{c}5.462 * * * \\
(2.002)\end{array}$ & $\begin{array}{c}0.926^{* * *} \\
(0.298)\end{array}$ & $\begin{array}{c}7.198 * * * \\
(1.874)\end{array}$ & $\begin{array}{c}0.851^{* * *} \\
(0.246)\end{array}$ & $\begin{array}{c}6.386^{* * *} \\
(1.598)\end{array}$ & $\begin{array}{c}0.913^{* * *} \\
(0.234)\end{array}$ \\
\hline $\begin{array}{l}\text { Minority shareholder } \\
\text { protection (HOST) }\end{array}$ & $\begin{array}{l}-1.009 \\
(0.958)\end{array}$ & $\begin{array}{c}-1.925^{* *} \\
(0.913)\end{array}$ & $\begin{array}{l}-1.175 \\
(0.946)\end{array}$ & $\begin{array}{r}-1.936 * * \\
(0.909)\end{array}$ & $\begin{array}{l}-0.119 * * \\
(0.0489)\end{array}$ & $\begin{array}{l}-0.113^{* *} \\
(0.0454)\end{array}$ & $\begin{array}{l}-0.0597 \\
(0.0534)\end{array}$ & $\begin{array}{l}-0.103 * * \\
(0.0468)\end{array}$ & $\begin{array}{c}-0.0832 * * \\
(0.0366)\end{array}$ & $\begin{array}{c}-0.0748 * * \\
(0.0353)\end{array}$ & $\begin{array}{l}-0.0507 \\
(0.0398)\end{array}$ & $\begin{array}{l}-0.0612^{*} \\
(0.0366)\end{array}$ \\
\hline $\begin{array}{l}\text { Inward foreign direct } \\
\text { investment }\end{array}$ & $\begin{array}{c}9.98 \mathrm{e}- \\
05 * * * \\
(2.24 \mathrm{e}-05)\end{array}$ & $\begin{array}{l}0.000102 * * * \\
(2.05 \mathrm{e}-05)\end{array}$ & $\begin{array}{c}9.97 \mathrm{e}- \\
05 * * * \\
(2.24 \mathrm{e}-05)\end{array}$ & $\begin{array}{l}0.000102 * * * \\
(2.05 \mathrm{e}-05)\end{array}$ & $\begin{array}{l}4.10 \mathrm{e}-06 * * * \\
(1.11 \mathrm{e}-06)\end{array}$ & $\begin{array}{c}4.29 \mathrm{e}- \\
06^{* * *} \\
(1.06 \mathrm{e}-06)\end{array}$ & $\begin{array}{l}4.28 \mathrm{e}-06^{* * *} \\
(1.12 \mathrm{e}-06)\end{array}$ & $\begin{array}{c}4.23 \mathrm{e}- \\
06 * * * \\
(1.06 \mathrm{e}-06)\end{array}$ & $\begin{array}{c}3.52 \mathrm{e}-06^{* * *} \\
(9.19 \mathrm{e}-07)\end{array}$ & $\begin{array}{c}4.25 \mathrm{e}- \\
06 * * * \\
(8.78 \mathrm{e}-07)\end{array}$ & $\begin{array}{l}3.68 \mathrm{e}-06 * * * \\
(9.23 \mathrm{e}-07)\end{array}$ & $\begin{array}{c}4.16 \mathrm{e}- \\
06^{* * *} \\
(8.80 \mathrm{e}-07)\end{array}$ \\
\hline Constant & $\begin{array}{l}-10.49 \\
(21.38)\end{array}$ & $\begin{array}{c}45.37 * * \\
(17.60)\end{array}$ & $\begin{array}{c}3.252 \\
(22.28)\end{array}$ & $\begin{array}{c}50.57 * * * \\
(17.70)\end{array}$ & $\begin{array}{c}-2.001 * * \\
(0.890)\end{array}$ & $\begin{array}{l}-0.0264 \\
(0.622)\end{array}$ & $\begin{array}{c}-2.896^{* * *} \\
(0.875)\end{array}$ & $\begin{array}{l}-0.200 \\
(0.627)\end{array}$ & & & & \\
\hline Constant cut 1 & & & & & & & & & $\begin{array}{r}2.068^{* *} \\
(0.832)\end{array}$ & $\begin{array}{c}0.155 \\
(0.656)\end{array}$ & $\begin{array}{c}2.358 * * * \\
(0.803)\end{array}$ & $\begin{array}{c}0.324 \\
(0.659)\end{array}$ \\
\hline Constant cut 2 & & & & & & & & & $\begin{array}{c}2.822 * * * \\
(0.833)\end{array}$ & $\begin{array}{c}0.901 \\
(0.656)\end{array}$ & $\begin{array}{c}3.114 * * * \\
(0.804)\end{array}$ & $\begin{array}{c}1.069 \\
(0.659)\end{array}$ \\
\hline
\end{tabular}


Observations

1,238
0.129

1,300
0.127

1,238
0.129

1,300

1,238

1,300

1,238

1,300

1,238

1,300

1,238

1,300

Robust standard errors in parentheses $* * * \mathrm{p}<0.01, * * \mathrm{p}<0.05, * \mathrm{p}<0.1$ 


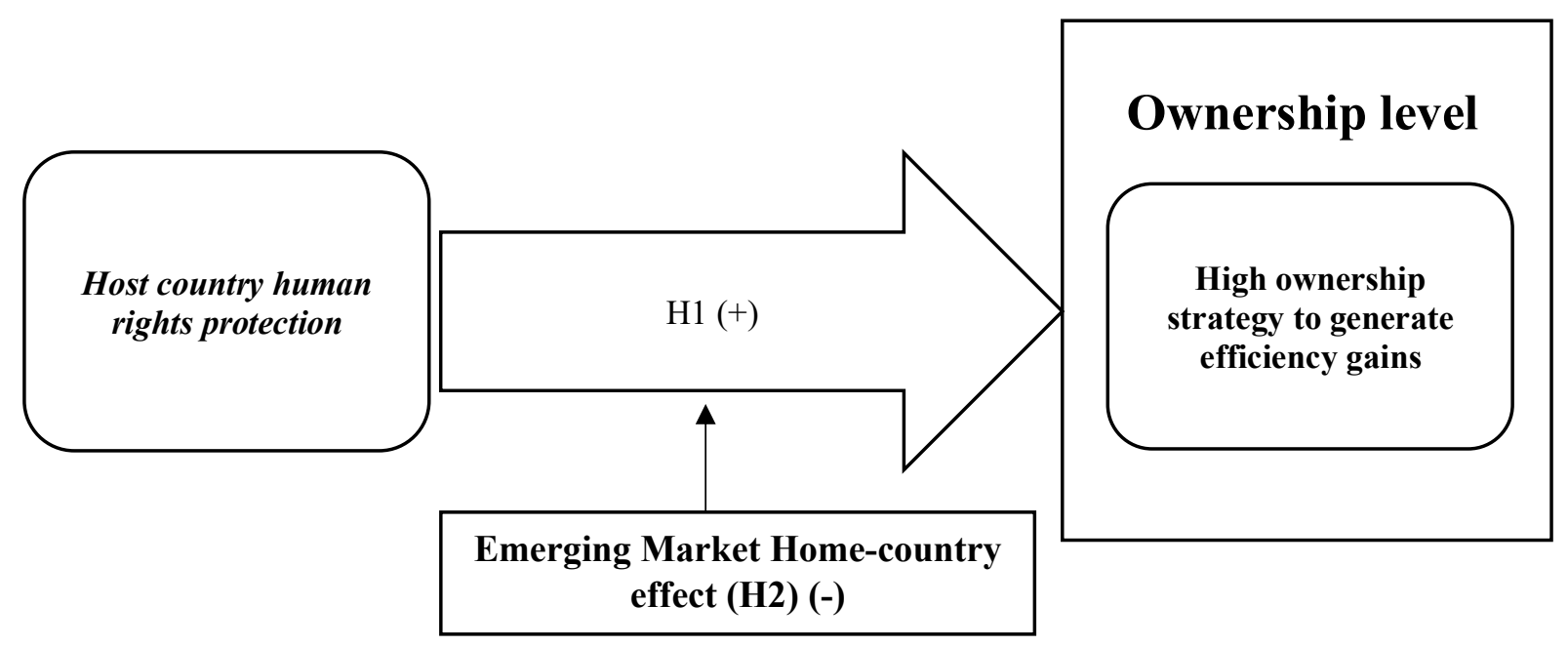

Figure 1. Conceptual framework of host country human rights protection and MNEs' ownership strategy 